\title{
Give-Constructions in Heritage Ambon Malay in the Netherlands
}

\author{
Francesca Moro \\ Radboud University \\ f.moro@let.ru.nl \\ Marian Klamer \\ Leiden University \\ M.A.F.Klamer@hum.leidenuniv.nl
}

\begin{abstract}
The domains where languages show variable syntax are often vulnerable in language contact situations. This paper investigates one such domain in Ambon Malay: the variable encoding of give-events. We study give-expressions in the Ambon Malay variety spoken by heritage speakers in the Netherlands, and compare the responses of heritage speakers with those of homeland speakers in Ambon, Indonesia. We report that heritage Ambon Malay shows an innovative higher incidence of Do constructions compared to the homeland variety, and a significant decrease in the frequency of 'two predicate' constructions. The change that heritage Ambon Malay is undergoing is thus not categorical, but rather involves a change in frequency of certain constructions. We argue that this 'restructuring by changing frequency' is due to a combination of factors: influence from Dutch, universal tendencies in language acquisition, and the language history of individual speakers. Apart from a quantitative difference, we also observe a qualitative difference between the give-constructions of heritage and homeland speakers of Ambon Malay: both groups use different prepositions in the prepositional object construction, a reflection of their different social histories.
\end{abstract}

\section{Keywords}

heritage language - Ambon Malay - Dutch-Ambon Malay bilingualism - dative alternation - double object construction 
In language contact situations, grammatical areas which allow variable syntax are often susceptible to change. This has been shown for domains like possessive encoding in Moroccan Arabic (Boumans, 2006), subordinate clauses in Turkish (Onar Valk and Backus, 2013), or object marking in Spanish (Montrul and Bowels, 2009). In many languages, the encoding of give-events also constitutes such a variable syntactic domain, as the Recipient-like argument $(\mathrm{R})$ and the displaced Theme $(\mathrm{T})$ argument ${ }^{1}$ involved in such events may be ordered in various ways, and receive different encodings - a variation commonly referred to in English as the 'dative alternation/shift' (Bresnan et al., 2007; Colleman, 2009; Broekhuis et al., to appear). The terms 'dative alternation' or 'dative shift' link together the 'Double Object (Do) construction', where R and T occur in a fixed order, and are not distinguished by any overt marking (John gave Mary a book), and the 'Dative construction', also known as 'Prepositional Object (PO) construction' where $\mathrm{R}$ is differentiated from $\mathrm{T}$ by being part of a prepositional phrase (John gave a book to Mary). In this paper we avoid using the notion 'dative', as Ambon Malay does not distinguish dative case, and refer to the two constructions as 'Double Object' (DO) and 'Prepositional Object' (PO) construction. ${ }^{2}$ In a canonical give-event, $\mathrm{R}$ and $\mathrm{T}$ do not have the same status in information structure, and this difference is reflected in how they are expressed (cf. Polinsky, 1998; Bresnan et al., 2007). $R$ is the participant that is presupposed to exist independently of the event, which is about the transfer of T. T is more focus-like, and $\mathrm{R}$ constitutes the more topic-like entity. As the previously activated ('known') topic that is accessible to both hearer and speaker, the $\mathrm{R}$ is more easily shortened or deleted than the $\mathrm{T}$. In contrast, the $\mathrm{T}$ is the element that is typically new information which the speaker wants to convey.

The variability of argument encoding found in give-constructions makes it an interesting domain of inquiry, not only from a monolingual perspective (Colleman, 2009; Theijssen, 2012, among others), but even more so from a language contact perspective (see Schoonbaert et al., 2007 for Dutch-English bilinguals; Yip and Matthews, 2007 for Cantonese-English bilinguals; Şahin and Kootstra, 2011 for Papiamento-Dutch bilinguals). For studies of language contact, the main interest of the give-constructions lies in the issue of what

1 We refer to these participants in give-events with the capitals $\mathrm{R}$ and $\mathrm{T}$, following conventions used in linguistic typology (see Dryer, 2007: 254, Malchukov et al., 2010: 1, Haspelmath, 2011: 540).

2 Other terms used in the literature to refer to the two constructions include 'indirective' versus 'double object' construction (Malchukov et al., 2010: 18), 'prepositional dative' versus 'double object' construction (Bresnan et al., 2007: 70; Colleman and Bernolet, 2012: 88). 
happens when patterns of variable argument encoding that exist in two languages are combined in the same bilingual speaker. Preliminary results of research investigating such combinations indicate that the expression of give-events is indeed a vulnerable domain which is subject to cross-linguistic influence. For example, Şahin and Kootstra (2011) have found significant crosslinguistic effects in the production of give-constructions by Papiamento-Dutch bilinguals. Similarly, Irizarri van Suchtelen (2014) has found significant changes in the dative constructions produced by heritage speakers of Spanish (all Dutch-Spanish bilinguals) compared to those produced by their monolinguals peers in Chile.

This article seeks to contribute to our understanding of cross-linguistic effects in the production of give-constructions by studying another heritage language: the Ambon Malay variety as spoken by heritage speakers in the Netherlands. Heritage speakers of Ambon Malay are second or third generation immigrants to the Netherlands who grew up as simultaneous or sequential Dutch-Ambon Malay bilinguals, with Dutch as dominant language. The central issue we address in this paper is: Has the give-construction in the heritage Ambon Malay of these bilingual speakers been restructured as compared to the Ambon Malay spoken in the homeland? And if restructuring of give-constructions in heritage Ambon Malay did take place, what did the change involve?

By comparing give-constructions used by heritage speakers with those used by homeland and first generation speakers, we find that heritage Ambon Malay has indeed been significantly restructured. What is particularly interesting is that this restructuring is not manifested as a categorical change in the grammar of heritage speakers, but it rather manifests itself as a significant change in the frequency with which certain constructions that exist in the homeland variety occur in the heritage language. In other words, heritage Ambon Malay is 'restructuring by changing frequency'. We argue that this is caused by a combination of factors: it is partly due to the different path of language acquisition that heritage Ambon Malay speakers underwent, and partly due to contact with Dutch, the dominant language. In addition, the amount of exposure that individual heritage speakers had to Ambon Malay in the course of their lifetime also explains some of the attested patterns.

This paper is structured as follows. In the remainder of this section (section 1.1) we present information on the social and linguistic history of heritage speakers of Ambon Malay in the Netherlands. In section 2 we describe how give-events are expressed in the languages of the bilingual heritage speakers: Ambon Malay (section 2.1) and Dutch (section 2.2). In section 3, we describe the design of the present study. Our results are presented and discussed in section 4 . Section 5 summarises the conclusions. 
1.1 Social and Linguistic History of Heritage Speakers of Ambon Malay

In the early 1950's, 12.500 speakers of Malay immigrated to the Netherlands (Veenman, 1994). They spoke Ambon Malay, the Malay variety spoken in Ambon Island in the Central Moluccas in eastern Indonesia since (at least) the $16^{\text {th }}$ century (Grimes, 1991; Paauw, 2008: $5^{2}$ ). Most of these immigrants had been soldiers in the Koninklijk Nederlandsch-Indisch Leger (KNIL) (the Royal Dutch-Indies Army) and had been staying in military barracks in Java and Sumatra for extensive periods. The Malay spoken in the KNIL barracks was Tangsi Malay, a variety structurally similar to other Malay varieties that contained elements from Ambon Malay, Javanese, as well as Dutch (Tahitu, 1989; Adelaar and Prentice, 1996). The ex-KNIL soldiers who left the Indonesian Republic with their families after Indonesia became independent thus brought along an Ambon Malay variety with Tangsi Malay influences. The descendants of these first generation immigrants in the Netherlands now number some 42.00o people, most of whom speak this Ambon Malay variety as a heritage language. After the Moluccans arrived in the Netherlands, they were housed in Moluccan kampen 'camps' and subsequently in special Moluccan wijken 'municipalities'. The Moluccan camps in particular were rather isolated, and this isolation strengthened the mutual links between the Moluccan inhabitants (Veenman, 1994).

The homeland and the heritage varieties of Ambon Malay thus began to diverge after the early 1950's. Three major factors account for this divergence: (i) a different path of acquisition of Ambon Malay by heritage speakers; (ii) influence from Dutch in the heritage speakers; and (iii) influence from Standard Indonesian in both heritage and homeland speakers. The Ambon Malay heritage speakers in our test group all grew up as simultaneous or sequential Dutch-Ambon Malay bilinguals (Table 3 in section 4.1.2 presents individual data). Although Ambon Malay was often the language they spoke at home, it was Dutch, as the national language of the Netherlands that is used in education and media, which became their dominant language as soon as they entered elementary school at the age of 4 . Both heritage and homeland speakers of Ambon Malay have been influenced by Standard Indonesian as this is the language that is typically used in the Moluccan churches in the Netherlands, and the national language of Indonesia. The schema in Fig. 1 summarizes the parallel developments of the heritage and homeland varieties of Ambon Malay.

Given this parallel development, we expect to find systematic differences between the Ambon Malay varieties spoken by heritage speakers, first generation speakers in the Netherlands and speakers who never left the homeland (see Tahitu, 1989; Huwaë, 1992; Voigt, 1994; Lekawael, 2011). 


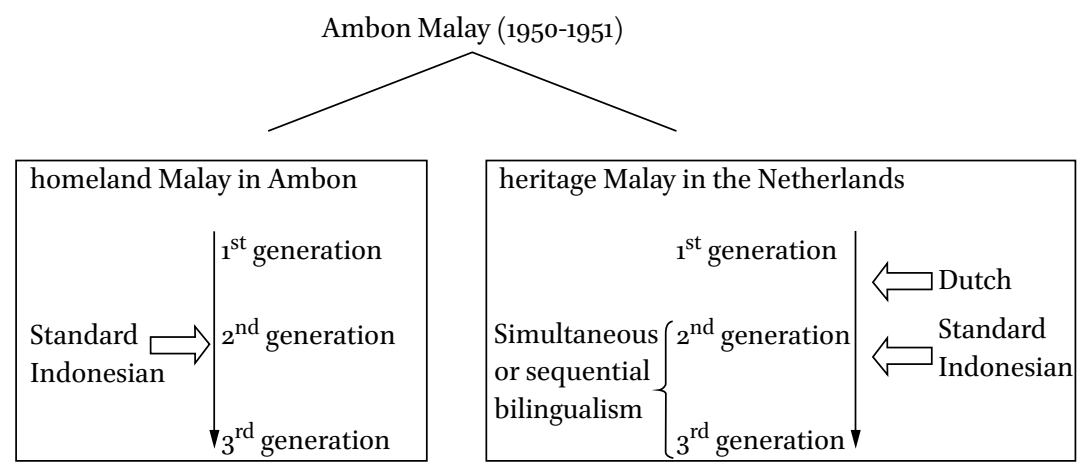

FIGURE 1 The parallel development of Ambon Malay in Ambon, Indonesia, and in the Netherlands

\section{$2 \quad$ Give-Constructions in Ambon Malay and Dutch}

In this section we present a descriptive overview of the various ways in which give-events are expressed in Ambon Malay and Dutch, the languages that are combined in the same, bilingual heritage speaker of Ambon Malay. We define give-events as involving verbs with a meaning of 'transfer' or 'caused possession', that are translated as 'give' or 'show' in English, and have three arguments: an Agent-like argument (A), a Recipient-like argument (R), and a Theme argument $(\mathrm{R}){ }^{3}$ We focus on describing those structural features that are relevant for answering the question how the give-constructions in the heritage language have been restructured as compared to the language of the homeland. The examples presented in this section and elsewhere in this paper are all from datasets collected by the first author. ${ }^{4} \mathrm{~A}$ description of the participants and the task is given in section 3.3.

\subsection{Give-Constructions in Ambon Malay}

In the domain of give-events, Ambon Malay allows five basic constructions. All these five constructions are attested in both homeland and heritage Ambon Malay.

3 Verbs for 'give' and 'show' are among the most typical and frequently found ditransitive verbs cross-linguistically: "It is striking that when a language has a closed class of ditransitive verbs, the same lexemes tend to recur in this class in language after language, most frequently verbs like 'give', 'show', 'teach'; sometimes also 'tell', 'send' and 'ask'.' (Malchukov et al., 2010: 50).

4 The heritage Ambon Malay data and the baseline Ambon Malay data were collected by the author and by Rosina Lekawael (2011), Jusmianti Garing and Feny Eky; the Dutch data were collected by Rowan Soolsma (2013). 
The first construction is the Prepositional Object (PO) construction, in which the Theme $(\mathrm{T})$ is a bare $\mathrm{N} P$, while the Recipient $(\mathrm{R})$ is encoded in a prepositional phrase, as illustrated in (1). As the examples show, different prepositions may be used to introduce the R. The preposition par 'for, to' (1a) is a lexeme that is often used in Po constructions in Ambon Malay (Van Minde, 1997: 76). Not being found in any other Malay variety, it can be considered a unique and typical feature of Ambon Malay. Apart from par, Ambon Malay may introduce the $\mathrm{R}$ with other prepositions that have similar or identical meanings, such as buat 'for, to', illustrated in (1b). Other prepositions that may be used are for 'for, to', ke 'to', kepada 'to', untuk 'for', and sama 'to, with' (cf. Paauw, 2008: 122). Kepada and untuk are recent loans from Standard Indonesian.

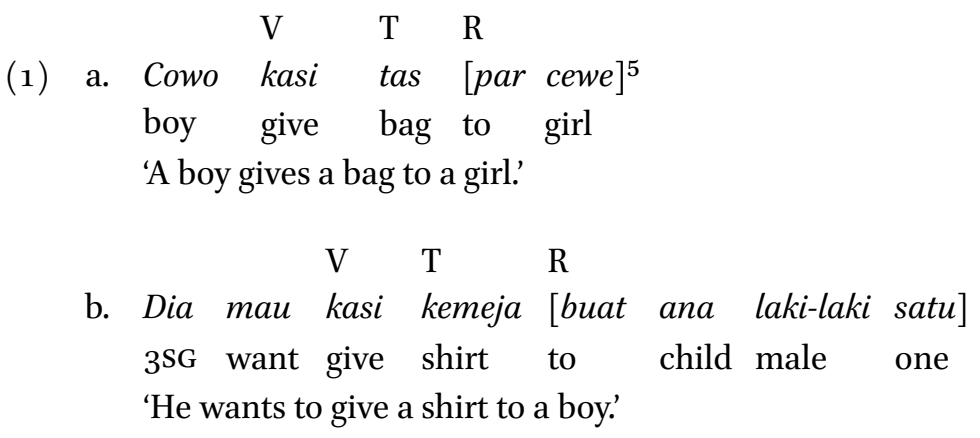

The variable choice of prepositions in Po constructions will be further discussed in section 4.2 below, where we will see that homeland and heritage speakers use different prepositions in Po constructions.

The second construction used in Ambon Malay give-expressions is the Double Object (DO) construction, in which the $\mathrm{T}$ and the R are both bare NPS, as illustrated in example (2).

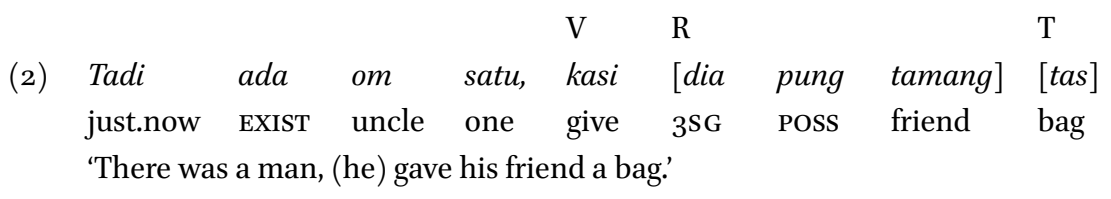

5 Abbreviations: ART $=$ Article, DEF $=$ Definite, EXIST $=$ Existential verb, $\mathrm{F}=$ Formal, $\mathrm{INDF}=$ Indefinite, $\mathrm{INF}=$ Infinitive, POSS $=$ Possessive, $\mathrm{SG}=$ singular, $\mathrm{REL}=$ Relative clause marker, $3=$ Third person. 
In Ambon Malay, PO constructions like those illustrated in (1a-b) are more frequent than Do constructions like (2) (Van Minde, 1997: 223). ${ }^{6}$ Additionally, it seems that DO constructions are more likely to occur when $\mathrm{R}$ is a pronoun (Van Minde, 1997: 222-223). In our homeland Ambon Malay data, the frequency of PO constructions is $72.90 \%$, against only $0.7 \%$ DO constructions (see Figure 2 below).

The third construction used in our dataset is the 'Recipient omission' construction, illustrated in (3), where the clause does not contain an overt expression of R:

\section{$\mathrm{V} \quad \mathrm{T}$ \\ (3) Tadi satu kasi [macang tas] \\ just.now one give sort.of bag \\ 'Someone just gives a sort of bag.'}

As mentioned in section 1 , in a canonical give-event, the $\mathrm{R}$ participant is presupposed to exist independently of the event, and constitutes a more topiclike entity than the transferred theme T, which is more focus-like (cf. Polinsky, 1998; Bresnan et al., 2007). It is thus expected that speakers leave the R unexpressed more often than they would omit the $\mathrm{T}$ when describing a give-event.

The fourth type of construction found in Ambon Malay is one that we will refer to as the 'two predicate' construction. A 'two predicate' construction expresses the give-event using two predicates in a single sentence. The $\mathrm{T}$ is expressed as the (only) argument of the first predicate (and not repeated with the second), while the $\mathrm{R}$ is introduced with the second predicate; see examples (4)-(5). In (4), the T tas 'bag' is introduced in the first part of the sentence as argument of the verb pegang 'hold, ${ }^{7}$ while the R dia pung teman 'his friend' is

6 Haspelmath, Michaelis and the APiCS Consortium (2013) represent Ambon Malay with a pie chart that has $75 \%$ PO and $25 \%$ DO, but it remains unclear where these percentages are based on. The reference they provide for the percentages is Van Minde (1997: 221), but no percentages are given on that page, or anywhere else in the source. On p. 223, Van Minde does however mention that "the majority" of sentences with 'give' use a po construction. Unfortunately, the grammar does not contain information about the type of data on which quantitative statements like these are based: corpus data, elicited data, or both.

7 Our data contains one instance where the $\mathrm{T}$ is introduced as part of the phrase denoting the Agent:

(i) Pace dengan krusli, mau kasi for itu mace man with muesli want give to that girl

'A man with (a box of) muesli, (he) wants to give (it) to the girl.'

This construction patterns with the 'two predicate' construction in that the $\mathrm{T}$ is introduced first, and is shared (but not repeated) with the second predicate, which introduces the R. 
introduced with the verb kasi 'give'. In the 'two predicate' constructions in our dataset, the first predicate is usually pegang 'hold', as in (4). However, the first predicate may also be a different verb, e.g. buka 'open' in (5), which introduces the T buku 'book', while R laki-laki satu 'one boy' is the argument of the second verb kasi 'give'.

$$
\begin{array}{llll}
\mathrm{V}_{1} & \mathrm{~T} & \mathrm{~V}_{2} & \mathrm{R}
\end{array}
$$

(4) Yang cowo satu ni, dia pegang [tas] terus dia kasi [par dia pung tamang] REL boy one this 3 SG hold bag next 3 SG give to 3 SG POss friend 'This boy here, he holds a bag, and then he gives (it) to his friend.'

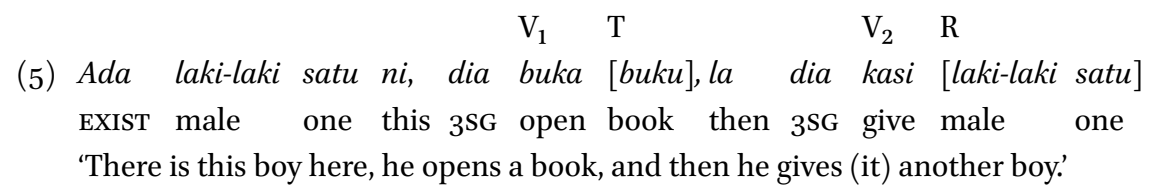

The 'two predicate' construction may consist of two clauses that are connected with a conjunction: terus 'next' in (4), la/lalu 'and then' in (5) are often used, as well as jadi 'so', langsung 'and then immediately', or dan 'and'. However, the clauses can also be simply juxtaposed without an overt linker, being separated with a pause, as shown in (6):

(6) Antua pegang $[$ kemeja $]$, mau kasi $^{9}$ par antua
3SG.F hold shirt
'He holds a shirt, (he) wants to give (it) to his child.'

'Two predicate' constructions such as those found in Ambon Malay are a typical feature of the Malay varieties that are spoken in eastern Indonesia. In these varieties, complex events tend to be expressed through two or more consecutive verbal predicates (referred to as 'serial verb constructions'10 in Paauw, 2008: 232-236; see also Moro, 2014).

8 In 'two predicate' constructions, $\mathrm{R}$ is most often encoded as part of a prepositional phrase, as illustrated in (4). However, our dataset has also instances where $R$ is expressed as a bare $\mathrm{NP}$, as shown in (5).

9 We consider auxiliary verbs such as mau 'want' (Van Minde, 1997: 192) to form a complex predicate with the main verb they precede. In (6), mau kasi 'wants to give' thus counts as one (complex) predicate.

10 We do not use this term here, as the 'two predicate' constructions in our data include various types of structures along the cline from 'serial verbs' to 'asyndetic parataxis' to 'conjoined clauses', as illustrated above. 
The fifth construction attested in our dataset is the 'argument fronting' construction. In such constructions, one of the two object arguments, mostly $\mathrm{T}$, is fronted to precede $\mathrm{A}$, while $\mathrm{R}$ is part of a prepositional phrase following the verb. This is illustrated in (7), where the T buku 'book' is fronted to the position preceding the A dia ' $3 S^{\prime}$ '. 11

(7) Jadi ini ada sebua buku, so this ExIsT one book

'So here there is a book,

$\mathrm{T} \quad \mathrm{V} \quad \mathrm{R}$

[buku] dia kasi tunju [par dia pung tamang]

book 3 sG give point to 3 sG Poss friend

(a) book he shows to his friend.'

In sum, our Ambon Malay dataset contains five types of constructions that express give-events: (i) the prepositional object (PO) construction, (ii) the double object (DO) construction, (iii) the Recipient omission construction, (iv) the 'two predicate' construction and (v) the 'argument fronting' construction. These constructions are used by all speakers of Ambon Malay, both homeland and heritage. The difference between homeland and heritage give-expressions does not lie in the type of constructions used, but rather involves a change in the frequency of certain constructions; we return to this in section 4.1. In addition, the expression of give-events in Ambon Malay shows variation in the choice of preposition that heads the prepositional phrase in the PO construction, a topic we return to in section 4.2.

\subsection{Give-Constructions in Dutch}

Being the dominant language of the Ambon Malay heritage speakers, it is likely that Dutch has influenced the way in which give-events are expressed in heritage Ambon Malay. In this section, we present a summary of the type of giveconstructions used by native speakers of standard Dutch. The Dutch speakers who provided the data reported here had no knowledge of Ambon Malay or Standard Indonesian (see also section 3.3).

The Dutch give-constructions allow alternations that involve a Po construction, as in (8), and a Do construction, as in (9). The preposition used in the prepositional phrase is always aan 'to'. The $\mathrm{R}$ argument may be omitted, as

11 In our dataset there are nine instances where $\mathrm{T}$ is fronted, against one instance where $\mathrm{R}$ is fronted. 
shown in (10). Dutch give-events are always expressed with a single verbal predicate.

$\begin{array}{llllllll}\text { (8) } & \mathrm{V} & \mathrm{T} & \mathrm{R} & & \\ \text { Een } & \text { man } & \text { geeft } & \text { [zijntas }] & {[\text { aan }} & \text { een } & \text { andere } & \text { man }] \\ \text { ART.INDF } & \text { man } & \text { give.3SG } & \text { 3SG.POSs bag } & \text { to } & \text { ART.INDF } & \text { other man } \\ \text { 'A man gives his bag to another man.' } & & & & \end{array}$

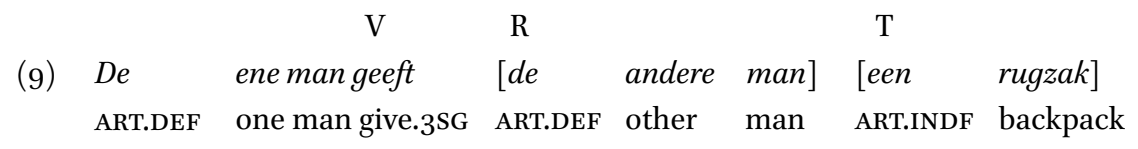
'The one man gives the other man a backpack.'

$\begin{array}{llllll}\text { (10) } & \text { Een } & \text { man laat } & {[\text { een }} & \text { boek }] & \text { zien } \\ \text { ART.DEF } & \text { man let.3SG } & \text { ART.INDF book } & \text { see.INF } \\ \text { 'A man shows a book.' } & & & \end{array}$

In standard Dutch, different types of factors determine the choice between a PO or a DO construction (cf. Broekhuis et al., 2015: 517-525, and references). Semantics plays a role: a Po construction is used when the referent of $\mathrm{T}$ undergoes a change of location, whereas a Do construction is used when the referent of $\mathrm{R}$ is expected to become the possessor of T. Another important factor in the choice for a DO or PO construction is the size of the object noun phrase: shorter noun phrases are often bare, and feature in Do constructions; while longer noun phrases are often part of prepositional phrases, and are typically placed at the end of the utterance by the "principle of end weight" (Wasow, 2002; Bresnan et al., 2007). Also, the animacy of the referents plays a role in the Do/PO alternation: canonically, $\mathrm{R}$ is animate and $\mathrm{T}$ inanimate, so that an inanimate $\mathrm{R}$ in a Do construction is less felicitous (Peter gaf Jan/ ?de bibliotheek het boek 'Peter gave John/?the library the book'). Further, the information packaging of the clause is relevant for the alternation: in a canonical give-event, if the $\mathrm{R}$ is given and $\mathrm{T}$ is new information, the Do construction is used; if $\mathrm{T}$ is given and $\mathrm{R}$ is new information, then a PO construction is used

And finally, different lexemes of transfer verbs show different biases for one construction over the other. For instance, the analytic causative laten zien 'to show' (lit. 'to let see') clearly prefers a Po construction, as in (11), while the verb tonen 'to show' does not have such a clear preference. 


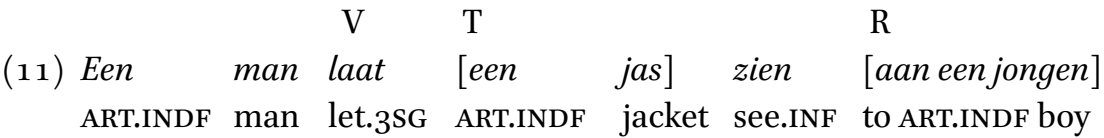

$$
\begin{aligned}
& \text { 'A man shows a jacket to a boy.' }
\end{aligned}
$$

In sum, Dutch objects are more likely to appear in DO constructions than in PO constructions when $\mathrm{R}$ is pronominal, definite, presuppositional, short, and animate; and when $\mathrm{T}$ is non-pronominal, indefinite, in focus, and long (Bresnan et al., 2007; Broekhuis et al., 2015: 524).

But this is not all there is to say about the Do/PO alternation: we know that the genre and context of the utterances also plays an important role. In particular, experimental and corpus data often show different, sometimes opposing, tendencies in frequencies of certain constructions. In the domain of Dutch give-expressions, it is reported that the verbs geven 'give' and tonen 'show' as used in corpora are skewed towards the Do construction (Colleman, 2006, 2009; Colleman and Bernolet, 2012: 94), while the same verbs show a strong preference for PO over Do constructions in de-contextualized experiments (Colleman and Bernolet, 2012: 96, 104). In other words, the choice for a Do or Po construction is also context-dependent.

In the Dutch data set that we analyzed, we see significantly more Po constructions than Do constructions (see Figure 2 below). We explain this preference for PO constructions as being due to the de-contextualized setting of the experiment (described in section 3). Such a setting involves an $R$ that is not presuppositional, and it typically requires the $\mathrm{R}$ to be expressed with a lexical nominal constituent that is not pronominal, and not short. In fact, many of the Dutch give-expressions in our data have an $\mathrm{R}$ that is quite long, as for example 'a girl on his right hand side' in (12). In all cases, the $\mathrm{R}$ is expressed with at least two words, as in (12)-(14), and most of the R's are indefinite noun phrases, as in (12) and (13), though definite ones also occur, as in (14). ${ }^{12}$

$\begin{array}{rlll}\text { (12) Ik } & \text { zie } & \text { een } & \text { man } \\ \text { I } & \text { see.1SG } & \text { ART.INDF } & \text { man }\end{array}$

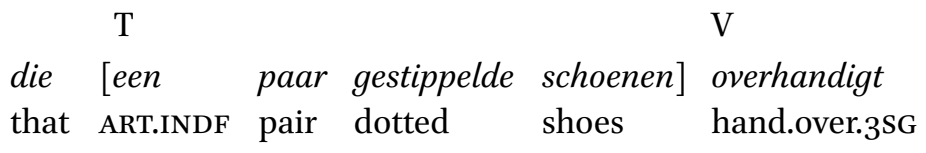

12 The responses had 28 indefinite Rs and 15 definite Rs. 
$\mathrm{R}$

[aaneen meisje aan zijn rechterkant]

to ART.INDF girl to 3 SG.POSS right.hand.side

'I see a man who hands over a pair of dotted shoes to a girl on his right hand side.'

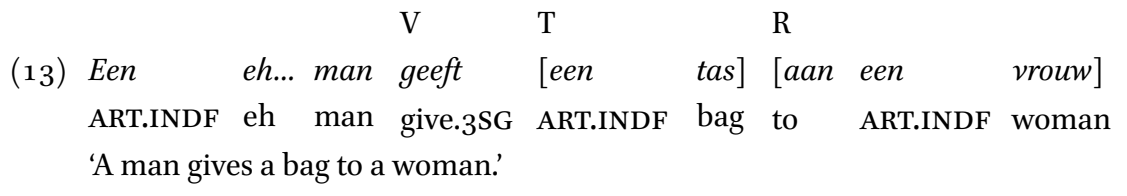

$\begin{array}{llll}\text { (14) Ik zie een } & \text { man met twee kinderen, } \\ \text { I see.1SG ART.INDF man with two children }\end{array}$

\begin{tabular}{|c|c|c|c|c|}
\hline V & $\mathrm{T}$ & & $\mathrm{R}$ & \\
\hline geeft & {$[e e n$} & paar schoenen] & [aan het & rechter \\
\hline give.3SG & ART.INDF & pair shoes & to ART.DEF & right.hand \\
\hline
\end{tabular}

'I see a man with two children, he gives a pair of shoes to the child on the right.'

Finally, Dutch allows one of the arguments, usually the T, to be fronted to the first position of a main clause, as in $(15) \cdot{ }^{13}$



$\mathrm{R}$

[aan de man die tegenover hem staat]

to ART.DEF man REL opposite him stand.3SG

'The bag in his right hand he hands over to the man who stands in front of him.'

13 Our dataset also contained a response like (i), where the $\mathrm{T}$ and the $\mathrm{R}$ are part of a subject relative clause:
(i) Een
man [die een boek
laat zien aan een andere man $]_{\text {Relative Clause }}$ ART.INDF man that ART.INDF book let.3SG see.INF to ART.INDF other man 'A man who shows a book to another man.'

Even though $\mathrm{T}$ precedes the verb here, we do not count this as an instance of ' $\mathrm{T}$ fronting', as it reflects the basic constituent order of Dutch subordinate clauses, which is always object-verb. 
In sum, Dutch has four constructions to express give-events: (i) the prepositional object (PO) construction, (ii) the double object (DO) construction, and (iii) the 'Recipient omission construction' and (iv) the 'argument fronting' construction. The frequency of the various constructions may differ depending on factors such as context and genre (natural corpus data versus elicited experimental data), or the category of $\mathrm{T}$ and $\mathrm{R}$ (noun or pronoun).

\subsection{Summary}

We have seen that in the domain of give-expressions, there are many similarities between Ambon Malay and Dutch. Both languages use the Po construction, the Do construction, the 'R omission' construction, and the possibility to front T. The 'two predicate' construction that is used in Ambon Malay is never used in Dutch. Finally, Ambon Malay allows six different prepositions to encode R, while Dutch only allows one.

\section{$3 \quad$ Research Design and Methodology}

\subsection{Objective}

The purpose of the present study is to examine how the give-construction in the Ambon Malay variety as spoken by heritage speakers in the Netherlands has been restructured as compared to the language of the homeland.

\subsection{Research Questions and Hypotheses}

We focus on the following two research questions: (i) Is the frequency of the attested constructions the same in heritage speakers and in homeland speakers? (ii) Do heritage speakers and homeland speakers select the same preposition to encode $\mathrm{R}$ in the PO construction? To answer these questions we first compare the patterns identified in heritage Ambon Malay with patterns in the Ambon Malay spoken by homeland speakers. Then we compare the patterns of heritage speakers to those of first generation speakers in the Netherlands (who are late bilinguals), and to those of Dutch speakers (with no knowledge of Ambon Malay). Given the small sample size of these last two groups, these latter comparisons are mostly qualitative in nature.

The typological similarities and differences between the Ambon Malay and Dutch give-expressions described in section 2 allow us to make the following predictions. First, we expect that heritage Ambon Malay diverges from homeland Ambon Malay with respect to the Do/PO alternation. Although both Dutch and Ambon Malay allow a choice between PO constructions and Do constructions, we saw in section 2 that different preferential tendencies exist: 
Ambon Malay prefers PO always, while Dutch has a bias for Do in corpus data, and for PO in de-contextualised elicited data. It has been demonstrated (Boumans, 2006; Onar Valk and Backus, 2013; Moro, 2014) that heritage speakers tend to adapt the frequency of a construction in the heritage language to the frequency of the 'corresponding' construction in their dominant language. In this case, this means that the frequency of PO and Do constructions in heritage Ambon Malay will be adapted to the Dutch frequencies, and thus be different from that of homeland Ambon Malay.

Second, we expect that the 'two predicate' construction is problematic for heritage speakers because this construction is not found in their dominant language Dutch. The choice between a 'two predicate' construction and a construction where only a single predicate is used relates to principles of information organization, and these principles are clearly different in Ambon Malay and Dutch. In Ambon Malay, the description of an event is often segmented into two or more predicates (referred to as a 'serial verb construction', Tjia, 1997; Van Staden and Reesink, 2008; Paauw, 2008), a pattern we also saw to occur in the give-expressions. In Dutch, however, give-expressions involve just a single verbal predicate. We know that principles of information organization are susceptible to considerable transfer effects in bilingual speakers (see Slobin, 1991; Carroll and von Stutterheim, 2003, among others), so we may expect heritage speakers to follow the Dutch principles, and use constructions with one single predicate more often than homeland speakers do.

Finally, given the many different prepositions allowed in the Po construction in Ambon Malay, and the different historical trajectories of these prepositions, we expect that the choice of prepositions by heritage speakers will be different from those used in the homeland variety.

\subsection{Participants, Task, and Responses}

Four groups of speakers participated in the study: one test group of heritage speakers and three control groups, as laid out in Table 1.

TABLE 1 Information about the number, gender and age of the participants in the four groups

\begin{tabular}{lllllll}
\hline & Group & $\begin{array}{l}\text { N. of } \\
\text { speakers }\end{array}$ & Female & Male & Age & $\begin{array}{l}\text { Std. } \\
\text { Deviation }\end{array}$ \\
\hline $\begin{array}{l}\text { Test } \\
\text { Group }\end{array}$ & Heritage & 32 & 16 & 16 & 43.78 & 12.641 \\
Control & Homeland & 27 & 16 & 13 & 43.04 & 18.392 \\
groups & First generation & 6 & 4 & 2 & 69.17 & 19.529 \\
& Dutch & 10 & 6 & 4 & 40 & 21.70 \\
\hline
\end{tabular}


The test group consists of 32 heritage speakers. In order to keep the sample as homogeneous as possible, individuals were selected from the same geographical areas in the Netherlands, namely the cities of Amsterdam, Nijmegen, Middelburg, and Vlissingen. In addition, speakers came from the same family as much as possible: the test group contains 6 couples of siblings, 4 couples of spouses, and 4 couples of parent-child. They all acquired Ambon Malay from birth in a naturalistic setting; typically at home. The age of onset of acquisition (AOA) of Dutch varied: 22 are simultaneous bilinguals (AOA Dutch: birth); 10 are sequential bilinguals (AOA Dutch: age 4-5). ${ }^{14}$ (Additional details on the background of the heritage speakers are provided in Table 3 in section 4.2.1.)

The first control group is formed by 27 homelands speakers. They are native speakers of Ambon Malay and currently live on Ambon or one of the surrounding islands. A few of them had some knowledge of English and other regional languages, but none of them could speak Dutch.

The second control group is formed by 6 first generation speakers of Ambon Malay in the Netherlands. They arrived in the Netherlands after the age of 14, and their mean length of residence is 48.67 years. Having learnt Dutch after puberty, they qualify as late bilinguals.

The third control group is formed by 10 native speakers of Dutch. None of them had any knowledge of Ambon Malay or Standard Indonesian.

The task we asked the participants to complete was to give an oral description of a series of six video clips that were shown to them on a laptop screen. The six video clips were intermingled with 62 distractor clips. Three of these video clips depict a person handing over an object (a pair of shoes or a bag) to another person, and three of them depict a person who is showing an object (a book or a jacket) to another person.

By using these materials, we controlled for three major factors that play a role in the choice between various available give-constructions: animacy, discourse accessibility and register (cf. Bresnan et al., 2007, and references cited there).

In our experiment, all participants described the same clips, so the animacy values of the arguments are kept constant: $A$ and $R$ are both animate (humans), while $\mathrm{T}$ is inanimate (e. g. bag, shoes, book). Additionally, the clips are canonical for a non-abstract use of 'give' and 'show'.

Second, we keep the discourse accessibility constant for all the arguments: none of them was previously 'given', as utterances elicited as responses to a clip

14 One person who participated in the experiment was excluded because the Ambon Malay variety that he uses shows too much influence from Standard Indonesian. In addition, he was the only participant who had no family relation with any of the other participants. 
in a test situation always lack a natural discourse context. Third, the register is kept constant, since the data were all oral retellings of clips. Any variation we find in the expression of 'give'-events we can thus interpret to be due to factors other than animacy value, discourse accessibility or register.

Every participant produced six responses. All the responses were transcribed and entered into a database. Not all responses were included in our analysis, as laid out in Table 2.

In the Ambon Malay dataset, we included responses with verbs of giving and showing: the most frequently used verbs are kasi 'give' (used 262 times), kasi tunju 'show' (lit. 'give show') (used 6o times), kasi lia(t) 'show' (lit. 'give see') (used 21 times) and tunju 'show' (used 9 times). Responses that were excluded contained verbs with a completely different meaning, such as kembali 'return', tukar 'change, exchange', dapat 'receive', jual 'sell', as well as reciprocals such as baku kasi 'give each other', baku tukar 'exchange with each other', and baku tawar 'offer to each other'.

In the Dutch give-constructions we elicited, the most frequent verbs were geven 'to give' (used 26 times) and laten zien 'to show' (lit. 'let see') (used 14 times)'. Additionally used verbs were tonen 'to show' (used 1 time), overhandigen 'to hand (over)' (used 3 times), and doorgeven 'to pass on' (used 2 times). As these verbs are all part of the class of Geven-werkwoorden 'Give-verbs' in Colleman's study of the Dutch dative alternation (2006: 437, Table 6.2), they were all included. Responses that were excluded contained verbs that are not in Colleman's Geven-werkwoorden class: aangeven 'hand (to)', toedraaien 'turn towards' and aanbieden 'offer'.

TABLE 2 Summary of valid and excluded responses in the four groups.

\begin{tabular}{lllr}
\hline Group & N. of speakers & Responses & \\
\hline Heritage Ambon Malay speaker & 32 & Valid & 181 \\
& & Excluded & 11 \\
Homeland Ambon Malay speaker & 27 & Valid & 140 \\
First generation Ambon Malay speakers & \multirow{2}{*}{6} & Excluded & 22 \\
& & Valid & 29 \\
Dutch speakers & \multirow{2}{*}{10} & Excluded & 7 \\
& & Valid & 46 \\
& & Excluded & 14
\end{tabular}




\section{4}

\section{Results and Discussion}

In this section, we present and discuss the results of our experiment. First, in section 4.1, we analyse the similarities and differences between all four groups with respect to the various types of constructions they use to express giveevents. Then, in section 4.2, we zoom in on the fact that different Ambon Malay speaker groups use different prepositions in a Po construction (as described in section 2.1). In each section we discuss the results and propose explanations for the patterns observed.

\subsection{Frequency of Give-Constructions \\ 4.1.1 Results}

Figure 2 lays out the results relative to the frequency of the five types of giveconstructions that are attested in our Ambon Malay data (see section 2.1). It shows that heritage Ambon Malay lies in between homeland Ambon Malay and Dutch. (Data about individual participants is provided in Appendix 1.)

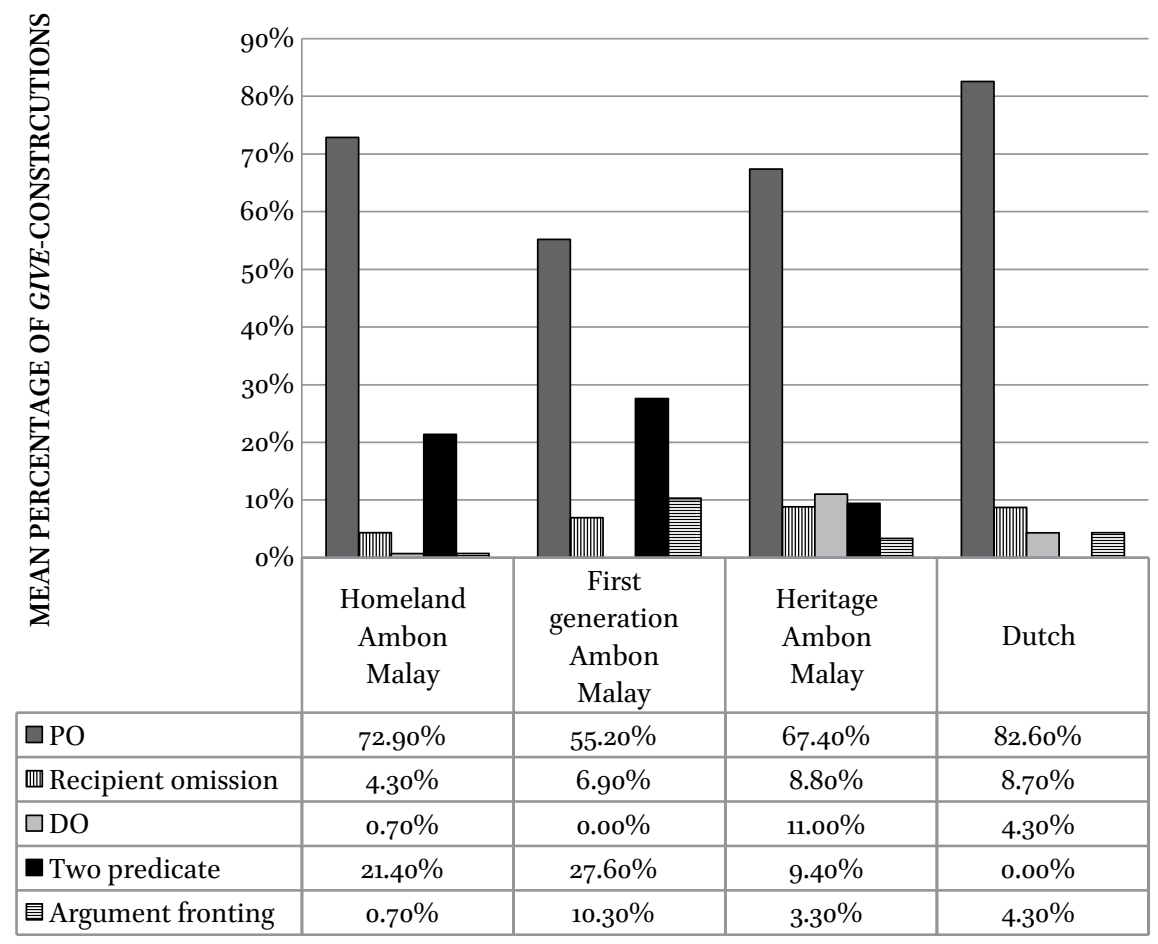

FIGURE 2 The mean percentages of the types of give-constructions attested in the four datasets 
All four groups show a strong preference for the structure involving a single predicate in a PO construction (dark gray bar). Thus, in preferring PO constructions to Do constructions, the four groups behave alike. Another similarity across all four groups is that 'Recipient omission' occurs with approximately the same frequency (vertical lines bar). This pattern may be explained by considering the discourse status of participants in a give-event, where $\mathrm{R}$ is a previously activated ('known') topic that is accessible to both hearer and speaker, and is thus more easily deleted than $\mathrm{T}$, the element that conveys the 'new information'.

Turning now to the differences between the heritage group and the homeland group: Figure 2 shows that these revolve around the 'Do construction' (light gray bar) and the 'two predicate' construction (black bar). Heritage Ambon Malay displays a significantly higher incidence of Do constructions when compared to homeland Ambon Malay $(t(57)=-3.274, p=.002) .{ }^{15}$ In the heritage group we find 20 tokens of Do constructions provided by 14 different speakers, while there is only one token of the Do construction in the homeland group. Interestingly, in the Dutch group, we find only two tokens of Do constructions, both provided by the same speaker.

On the other hand, heritage speakers show a significantly lower incidence of 'two predicate' constructions when compared to homeland speakers $(t(57)=$ $2.804, p=.007$ ) and to first generation speakers. In the heritage group, only 12 speakers out of 32 provided at least one 'two predicate' construction, while in the homeland group 17 speakers out of $26 \mathrm{did}$, and in the first generation group all six speakers provided at least one 'two predicate' construction. Thus, while the 'two predicate' construction is used by heritage speakers, they use it much less than the homeland and first generation speakers.

Finally, with respect to the 'argument fronting' construction (horizontal lines bar), the heritage Ambon Malay group patterns with the first generation group. (In the Dutch group only two tokens of this construction are attested). Increased use of a fronting strategy may be related to speakers having difficulties in accessing lexical items. It is known from the literature that speakers who have word finding problems (such as heritage speakers or elder speakers) tend to front well-known words in order to gain time when producing an utterance (see Aalberse and Muysken, 2013: 11). However, given the overall paucity of this construction in our data, it will not be considered further here.

15 We used the more conservative two-tailed test because we wanted to be neutral with respect to the direction of the effect and take into account any possible difference. 


\subsubsection{Discussion}

Three main results emerge from the quantitative analysis of the data: (1) PO constructions are equally frequent in the homeland and heritage groups (as well as in the first generation and in the Dutch groups); (2) Do constructions are used significantly more in the heritage group; (3) 'two predicate' constructions are used significantly less in the heritage group. We will discuss these three findings here in turn.

We suggest that PO constructions are stable in the heritage language because they are the preferred strategies in both Ambon Malay and Dutch (see section 2). It seems that Ambon Malay prefers Po constructions always, independent of context. In contrast, Dutch has a clear bias to PO constructions only in experimental settings. ${ }^{16}$ The preference for Po in our heritage Ambon Malay data can thus be seen as a reflection of the overall preference to use PO constructions in both languages spoken by the heritage speakers, in a decontextualised experimental setting like ours. In a study on a Malay-Portuguese creole, Baxter (1990: 182) states that "the best chance for a feature to become dominant in a creole is where there is a conspiracy between more than one source: superstrate / substrate / creole universals". If we extend this claim from creole to heritage languages, we can say that the best chance for a feature to become dominant in a heritage language is where there is conspiracy between the homeland language and the dominant language. Being a feature that conspires between homeland Ambon Malay and Dutch, the Po construction becomes dominant in heritage Ambon Malay.

Although the PO construction is dominant in Ambon Malay, the language also uses Do constructions, see Fig. 2. Recall that in natural speech, Do constructions are more likely to occur with a pronominal R (see section 2.1). In our experimental setting, however, responses depict decontextualized events where the $\mathrm{R}$ is not presupposed and not definite. Hence, reference to $\mathrm{R}$ is less likely to occur with a pronominal form in a Do construction. In other words, our setting predicts a bias for PO constructions over Do constructions. In this light, it is interesting to observe that heritage speaker still use Do constructions with a significantly higher frequency when compared to homeland speakers. How can we explain this?

We propose that the Do constructions in heritage speakers result from two forces that apply at the same time: (i) indirect transfer from the dominant language Dutch, and (ii) a universal tendency to favour Do constructions in

16 In the picture description task reported in Colleman and Bernolet (2012: 96), the elicited sentences showed a preference for PO (54.1\%) over Do (13.9\%). 
acquisition. These two forces are probably interrelated, but for sake of clarity we discuss them separately here.

In the heritage contact scenario, syntactic change nearly always involves an adaptation in the frequency distribution of patterns that already existed in the recipient heritage language (Silva-Corvalán, 1993, 1994, 2008). When two languages have been in contact for a limited amount of time (in our case only 60 years), transfer of a structure from the dominant language is more likely to occur when that structure is already present in the heritage language. That is, when speakers find evidence for a construction in both their dominant language and their heritage language, that construction becomes more entrenched and more productive (see Backus 2004). The point made by Backus (2004), Silva-Corvalán (2008) and Muysken (2013) is that a structure that is shared among dominant and heritage language is likely to show an increase in frequency in the heritage language. This kind of 'system-preserving change' (Backus, 2004: 180) may be referred to as a form of 'indirect transfer' (cf. Muysken, 2013: 721). As a construction that is grammatical in both Dutch and Ambon Malay, heritage speakers perceive that the Do construction in the dominant language, Dutch, has a structural counterpart in the recipient heritage language, Ambon Malay, and as a result they use this construction more frequently.

Apart from indirect transfer, there may be another factor responsible for the higher incidence of Do constructions in heritage Ambon Malay. Universal grammar, defined here as a set of universal tendencies in language encoding, may have forced or facilitated change in the heritage language. We know that Do constructions spontaneously emerge in contact varieties such as creoles: the APiCS reports that Do constructions are found in the majority of creoles (6o out of 76), and Bruyn et al. (1999: 330) show that they are found even in those creoles whose lexifier languages have no Do constructions. It has been suggested (e.g. Michaelis and Haspelmath, 2003) that the substrate may have played a role in the genesis of Do constructions in creoles, as Do constructions are found widely in the languages of West Africa. However, an argument against the substrate influence is that we know of no other West African structural feature that has had such a categorical pan-creole effect, going against the categorical word order in their lexifiers in the case of Romance-lexicon creoles (Pieter Muysken, personal communication). In addition, a number of studies report that Do constructions are overgeneralized by children during the course of L1 and L2 acquisition (see Mazurkewich and White, 1984; Whong-Barr and Schwartz, 2002, among others). In other words, data from creoles and from language acquisition suggests that there is something special or iconic about Do constructions that makes this feature likely to be selected in language contact situations. 
To sum up, the innovative use of Do constructions in heritage Ambon Malay is the result of two forces: a process of 'indirect transfer' from Dutch, and universal tendencies in language acquisition which favour Do constructions. These two forces are not easy to tease apart and it is reasonable to assume that they act in a cumulative way (Polinsky and Kagan, 2007: 382 ). ${ }^{17}$

The third finding we discuss here is that 'two predicate' constructions are used less frequently by heritage speakers than by homeland (and first generation) speakers, as shown in Fig. 2. Put differently, homeland speakers are more likely to describe the visual stimuli by using two predicates. This pattern reflects a way of segmenting the flow of information which is typical of Ambon Malay (Tjia, 1997; Van Staden and Reesink, 2008). The shifting preference patterns where heritage speakers strongly prefer constructions with only one predicate suggests that they apply different information organization principles (Slobin, 1991; Carroll and von Stutterheim, 2003). Heritage speakers appear to organize information via their dominant language, Dutch, where give-events are prototypically expressed with a single verbal predicate (section 2.2).

Further evidence for the claim that heritage speakers express events using the organizing principles of Dutch rather than of Ambon Malay comes from data on another type of semantically complex events - resultative constructions - collected from the same speaker groups (Moro 2014). In a video-retelling task eliciting resultative constructions (i.e. 'break a stick (in two)', 'tear a piece of cloth (in two)'), homeland and first generation speakers used a construction involving two predicates (either verb serialization or a sequence of two coordinated clauses) in $57.58 \%$ of the responses, while heritage speakers did so only in $15.94 \%$ of the responses.

These data indicate that heritage speakers are shifting towards a Dutch-like way of organizing information using one predicate instead of two, and that this shift involves various syntactic domains, including the expression of giveevents and of resultative events.

In arguing about the degree of restructuring of heritage speakers' grammars it is important to consider individual's data, since heritage speakers are known to have variable language background and proficiency. We therefore

17 One way to tease apart these two forces would be to study heritage speakers of Ambon Malay with a dominant language that does not allow Do constructions, such as Italian. If this hypothetical group also shows a higher rate of Do constructions compared to homeland speakers, then we can conclude that universal tendencies are the main force at work. If, conversely, heritage Malay speakers with Italian as dominant language do not show a higher rate of Do, then we can conclude that, in the case of heritage Malay speakers in the Netherlands, transfer from Dutch is the major force. 


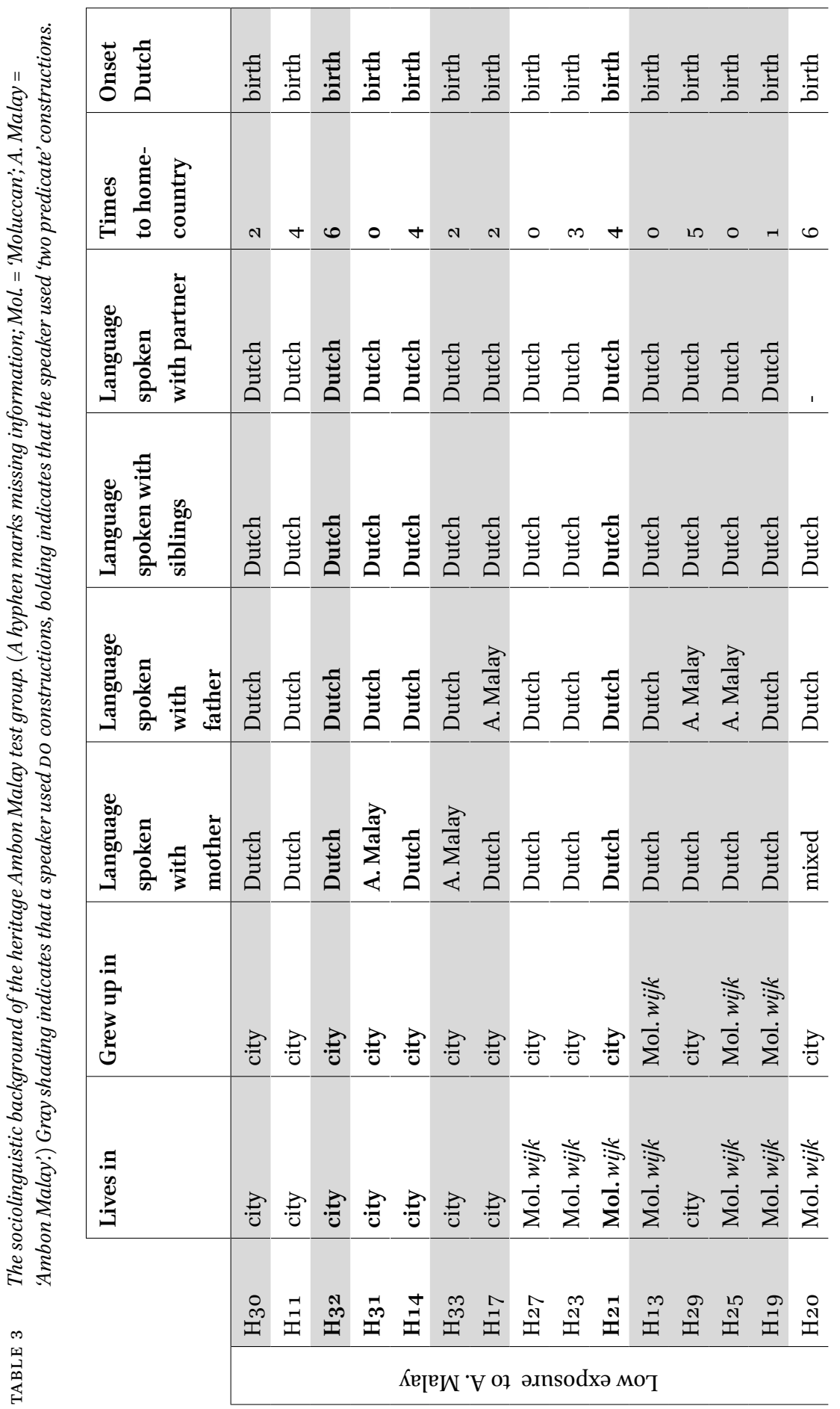


GIVE-CONSTRUCTIONS IN HERITAGE AMBON MALAY IN THE NETHERLANDS 285

\begin{tabular}{|c|c|c|c|c|c|c|c|c|c|c|c|c|c|c|c|c|}
\hline 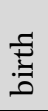 & है를 & 胥: & ق & 胥 & قี & 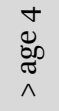 & $\begin{array}{l}+ \\
\stackrel{+}{0} \\
\underset{\sim}{\infty}\end{array}$ &  & 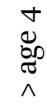 & $\begin{array}{l}+ \\
\stackrel{0}{*} \\
\underset{\sim}{*}\end{array}$ & 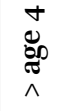 & $\begin{array}{l}+ \\
\stackrel{\sigma}{\sigma} \\
\wedge \\
\wedge\end{array}$ & $\begin{array}{l}+ \\
\underset{\sim}{\infty} \\
\wedge \\
\wedge\end{array}$ & ت: & $\begin{array}{c}+ \\
\underset{\sim}{\infty} \\
\underset{\wedge}{\infty}\end{array}$ & $\underset{\sim}{+}$ \\
\hline$m$ & 0 & $\neg$ & I & $n$ & $m$ & $\nabla$ & $\stackrel{ }{\rightarrow}$ & 1 & 10 & N & $n$ & 0 & $\infty$ & N & $\stackrel{0}{-}$ & $\infty$ \\
\hline 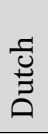 & 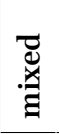 & 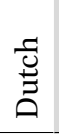 & 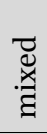 & 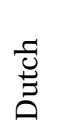 &  & 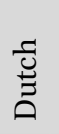 & $\begin{array}{l}\frac{\tilde{U}}{0} \\
\stackrel{\Xi}{\Xi} \\
0\end{array}$ & 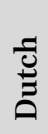 & 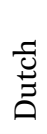 & 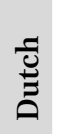 &  & 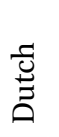 & 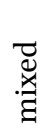 & $\underset{i}{\stackrel{\vec{J}}{\pi}}$ & $\begin{array}{l}\stackrel{\overbrace 0}{0} \\
\stackrel{\Xi}{0}\end{array}$ & $\frac{\vec{\pi}}{\sum_{i}^{\pi}}$ \\
\hline 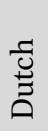 & 总 & 总 & 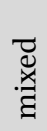 & 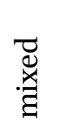 & 苞 & 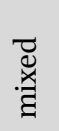 & 芯 & 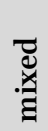 & 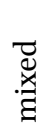 & 芯 & 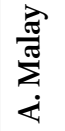 &  & 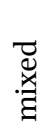 & 芯 & 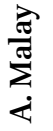 & 矛 \\
\hline $\begin{array}{l}\text { 苍 } \\
\stackrel{\Xi}{*} \\
0\end{array}$ & 总 & 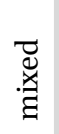 & $\frac{\vec{\pi}}{\sum_{\pi}^{\pi}}$ & $\begin{array}{l}\frac{\vec{\pi}}{\pi} \\
\dot{\pi} \\
\dot{\pi}\end{array}$ & $\frac{\vec{\pi}}{\sum_{i}^{\pi}}$ & $\begin{array}{l}\frac{\vec{\pi}}{\pi} \\
\sum \\
\dot{\pi}\end{array}$ & 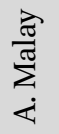 & 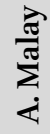 & $\begin{array}{l}\frac{\vec{\pi}}{\pi} \\
\sum_{i}^{\frac{\pi}{\pi}}\end{array}$ & 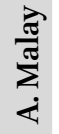 & 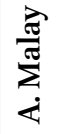 & $\begin{array}{l}\frac{\vec{\pi}}{\pi} \\
\underset{\Sigma}{\pi}\end{array}$ & $\begin{array}{l}\frac{\vec{\pi}}{\pi} \\
\sum_{i} \\
\dot{<}\end{array}$ & 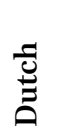 & 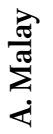 & 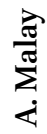 \\
\hline 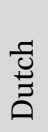 & 总 & 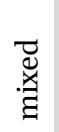 & 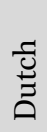 & $\sum_{\dot{<}}^{\frac{\vec{\pi}}{\pi}}$ & 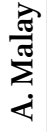 & $\underset{\dot{\Sigma}}{\frac{\vec{\pi}}{\pi}}$ & 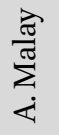 & 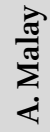 & 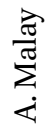 & $\underset{\dot{i}}{\stackrel{\vec{\pi}}{\operatorname{m}}}$ & 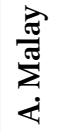 & $\begin{array}{l}\underset{\pi}{\pi} \\
\sum_{i}^{\pi} \\
\dot{\Sigma}\end{array}$ & $\begin{array}{l}\frac{\vec{\pi}}{\pi} \\
\sum_{i} \\
\dot{<}\end{array}$ & 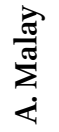 & 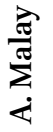 & 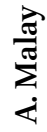 \\
\hline $\begin{array}{l}\text { ह్ష } \\
\text { త్ } \\
\dot{0} \\
\text { ¿ }\end{array}$ & 胥 & $\begin{array}{l}\frac{y}{:=} \\
\dot{3} \\
\dot{0}\end{array}$ & 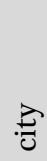 & & $\stackrel{\overrightarrow{0}}{0}$ & $\begin{array}{l}\text { छ्ञ్ } \\
\tilde{J} \\
\dot{0} \\
\stackrel{0}{\Sigma}\end{array}$ & 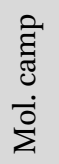 & 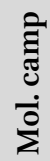 & \begin{tabular}{l}
$\frac{\pi}{3}$ \\
$\stackrel{0}{3}$ \\
\multirow{3}{*}{}
\end{tabular} &  & 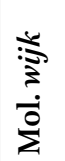 & 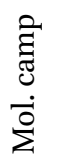 & $\begin{array}{l}\text { छ్ } \\
\text { đु } \\
\dot{0} \\
\dot{0}\end{array}$ &  & 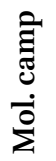 & 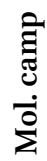 \\
\hline 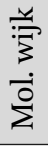 & $\begin{array}{l}\stackrel{3}{3} \\
\dot{0} \\
\stackrel{0}{\Sigma}\end{array}$ & $\begin{array}{l}\frac{y}{3} \\
\dot{3} \\
\dot{0}\end{array}$ & $\begin{array}{l}\frac{y}{3} \\
\dot{3} \\
\dot{0} \\
\dot{\Sigma}\end{array}$ & 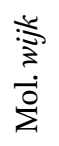 & 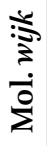 & 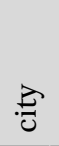 & 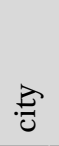 & $\begin{array}{l}\frac{1}{3} \\
\stackrel{0}{0} \\
\dot{0}\end{array}$ & 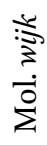 & 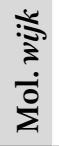 &  & 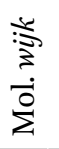 & 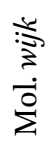 & 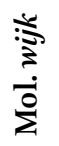 & 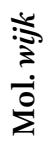 &  \\
\hline$\stackrel{N}{N}$ & $\stackrel{\infty}{=}$ & $\widehat{\underline{I}}$ & $\bar{I}$ & 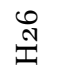 & $\stackrel{10}{7}$ & $\stackrel{\infty}{N}$ & $\stackrel{\text { N }}{\text { I }}$ & $\bar{N}$ & $\stackrel{9}{I}$ & $\Xi$ & $\stackrel{\infty}{=}$ & $\stackrel{10}{11}$ & $\bar{J}$ & $\stackrel{m}{ت}$ & $\Xi$ & $\stackrel{N}{I}$ \\
\hline
\end{tabular}


investigated if there was a relation between the amount of exposure that individuals had to Ambon Malay in the course of their lifetime and their use of the Do construction and the 'two predicate' construction. We divided the heritage speakers in our experiment into two groups according to the amount of exposure they had to Ambon Malay: 'LOW EXPOSURE' vs. 'MEDIUM-HIGH EXPOSURE', see Table 3.

Exposure to Ambon Malay was calculated on the basis of the following parameters: (i) place where they currently live (either a Moluccan wijk 'municipality', or a city), (ii) place where they grew up (in a Moluccan camp, a Moluccan wijk, or a city), (iii) language spoken (usually) with mother, father, siblings and partner (Ambon Malay, Dutch or a mix of these), (iv) how many times they visited the home-country, and (v) onset of acquisition of Dutch. Speakers using Do constructions are shaded grey, speakers using the 'two predicate' construction are printed in bold.

From the information presented in Table 3, three observations can be made. First, of the heritage speakers who use Do constructions (shaded grey) most belong to the 'LOW EXPOSURE' group. They grew up as simultaneous bilinguals and spoke mainly Dutch in the family. Half of them live in cities, and are thus completely immersed in a Dutch speaking environment. Second, of the speakers who use the 'two predicate' construction (printed in bold) most belong to the 'MEDIUM-HIGH' exposure group. These speakers report that they spoke mainly Ambon Malay in the family during their childhood. Third, overall, speakers who use Do constructions do not use 'two predicate' constructions, and vice versa (speakers $\mathrm{H}_{1} 6, \mathrm{H}_{2}, \mathrm{H}_{3} 2$ are the only exceptions). The fact that one and the same speaker typically does not use both of the constructions confirms their different 'origin': the Do construction is an innovation that occurs in speakers who had relatively low exposure to Ambon Malay, while the 'two predicate' construction is a typical Ambon Malay feature maintained by speakers with a medium-high exposure to Ambon Malay.

In sum, the information on the language history of the speakers suggests that low exposure to Ambon Malay is related to the use of Do constructions as an innovation in the heritage variety. In contrast, high exposure to Ambon Malay relates to the use of the 'two predicate' construction, a feature typical of the homeland variety.

\subsection{Preposition Selection}

In our Ambon Malay data, seven prepositions are used to encode the PO (section 2.1). In this section we report the differences in preposition selection, and offer an explanation for the attested variation. 


\subsubsection{Results}

The use of prepositions in the Po construction by the three Ambon Malay speaker groups is presented in Table 4. Seven preposition are used, with similar meanings: par 'for, to', for 'for, to', buat 'for, to', untuk 'for', ke 'to', kepada 'to' and sama 'to, with' (see section 2.1 for illustrations). We compared with an independent $t$-test only the means of the homeland and the heritage group, as the number of first generation speakers is too small to allow a reliable statistical analysis.

Table 4 shows that with respect to preposition selection, first generation speakers pattern with heritage speakers, not with homeland speakers. While homeland speakers show a very strong preference for par 'to' (65.48\%), the other two groups prefer the preposition buat 'for, to' and untuk 'for'. The only

TABLE 4 The mean percentages of the different prepositions attested in the Ambon Malay datasets. Asterisks indicate statistically significant differences, the hyphen marks missing information

\begin{tabular}{|c|c|c|c|c|c|}
\hline Preposition & Group & $\mathbf{N}$ & Mean & Std. Deviation & Sig. (2 tailed) \\
\hline & Homeland & 27 & $65.48 \%$ & 0.36689 & \\
\hline \multirow[t]{3}{*}{ par } & Heritage & 32 & $2.59 \%$ & $0.085^{23}$ & $.000^{* * *}$ \\
\hline & First generation & 6 & $17.83 \%$ & 0.22275 & \\
\hline & Homeland & 27 & $22.07 \%$ & 0.34972 & \\
\hline \multirow[t]{3}{*}{ for } & Heritage & 32 & $20.81 \%$ & 0.36232 & .893 \\
\hline & First generation & 6 & $18.33 \%$ & 0.28577 & \\
\hline & Homeland & 27 & $1.89 \%$ & 0.05444 & \\
\hline \multirow[t]{3}{*}{ buat } & Heritage & 32 & $32.50 \%$ & 0.34839 & $.000^{* * *}$ \\
\hline & First generation & 6 & $30.67 \%$ & 0.42744 & \\
\hline & Homeland & 27 & $0.00 \%$ & 0.00000 & \\
\hline \multirow[t]{3}{*}{ untuk } & Heritage & 32 & $14.69 \%$ & $0.2755^{1}$ & $.008^{* *}$ \\
\hline & First generation & 6 & $16.67 \%$ & 0.40825 & \\
\hline & Homeland & 27 & $3 \cdot 78 \%$ & 0.12601 & \\
\hline \multirow[t]{3}{*}{$k e$} & Heritage & 32 & $4 \cdot 38 \%$ & 0.12528 & .856 \\
\hline & First generation & 6 & $0.00 \%$ & 0.00000 & \\
\hline & Homeland & 27 & $0.00 \%$ & 0.00000 & \\
\hline \multirow[t]{3}{*}{ kepada } & Heritage & 32 & $4.88 \%$ & 0.13341 & .063 \\
\hline & First generation & 6 & $0.00 \%$ & 0.00000 & \\
\hline & Homeland & 27 & $0.00 \%$ & 0.00000 & \\
\hline \multirow[t]{2}{*}{ sama } & Heritage & 32 & $0.00 \%$ & 0.00000 & - \\
\hline & First generation & 6 & $2.83 \%$ & 0.06940 & \\
\hline
\end{tabular}


preposition attested with a similar frequency across the three groups is for 'for, to'. The remaining three prepositions ke 'to', kepada 'to' and sama 'to, with' are not very frequent. $\mathrm{Ke}$ occurs both in homeland speakers and in heritage speakers, while kepada is found only in heritage speakers (9 tokens). Finally, there is only one token of sama which was produced by a first generation speaker.

\subsubsection{Discussion}

We propose that heritage speakers show a preference for buat, because buat was the most frequent form in the input they had from their parents. In other words, the Ambon Malay variety spoken by the first generation differs in choice of preposition from the one currently spoken by homeland speakers in Ambon, and the heritage speakers reflect the preposition choice of the first generation.

The incongruence between choice of preposition by first generation and homeland speakers has an obvious historical explanation. As discussed in section 1.1, the majority of the Moluccan KNIL-soldiers and their families who were shipped to the Netherlands spoke Ambon Malay with Tangsi Malay influences. It is likely that buat was used in Tangsi Malay, as it is the preposition that is prototypically used to mark a PO in give-constructions in numerous varieties of Malay, as well as in colloquial Indonesian (Paauw, 2008, Van Minde, 1997: 184). Heritage speakers thus find evidence for buat not only in their parental language but also when they interact with Malay speakers from other parts of the Indonesian archipelago.

Par, on the other hand, is a lexeme unique to Ambon Malay. It was brought along by Moluccan immigrants to the Netherlands, and was thus part of the input of heritage speakers. In addition, par has also spread in the Ambon Malay community of the Netherlands because heritage speakers visit Ambon and new Ambon Malay speaking immigrants arrive in the Netherlands.

Unlike par and buat, the prepositions untuk, ke, kepada and sama are not prototypically used in Ambon Malay give-constructions: $k e$ means 'to' and marks a direction or a goal, kepada introduces an animate recipient in very formal contexts, untuk indicates a beneficiary rather than a recipient, and sama 'be equal to, to, with' is a multifunctional preposition that usually has a comitative meaning. Kepada, and most probably untuk as well, are recentloan from Standard Indonesian. It is probable that heritage speakers picked them up in the Moluccan churches in the Netherlands (where services are conducted in Standard Indonesian), through interactions with Indonesian speaking people in the Netherlands (relatives, or clergypersons), or when visiting Indonesia. It has been observed (see Chevalier 2004 and references therein) that heritage speakers show difficulties in understanding and mastering the complete range of registers and styles available to monolingual 
homeland speakers. This may account for their use of more 'formal' prepositions such as kepada in the give-constructions elicited by the video-clips.

In sum, in their choice of prepositions in the PO construction, heritage speakers resemble first generation speakers, and differ from homeland speakers of Ambon Malay. The choice of prepositions in the heritage language shows traces of Tangsi Malay, and also of interactions with speakers of Standard Indonesian. As such it reflects the different social histories of heritage and homeland speakers.

\section{5}

\section{Conclusions}

Ambon Malay has five constructions to express give-events: (i) the prepositional object (PO) construction, (ii) the double object (DO) construction, (iii) the Recipient omission construction, (iv) the 'two predicate' construction and (v) the 'argument fronting' construction. These constructions are used in both the homeland and the heritage varieties. However, heritage Ambon Malay diverges from the homeland variety in a number of ways. First, heritage Ambon Malay shows an innovative higher incidence of Do constructions. We propose that this 'systempreserving change' is the result of two forces, acting in a cumulative way: a process of 'indirect transfer' from Dutch, and universal tendencies in language acquisition which favour DO constructions. The language history of the individual heritage speakers confirms our analysis that a higher incidence of Do constructions is related to a history of low exposure to Ambon Malay.

Heritage Ambon Malay also differs from the homeland variety in that it shows a lower incidence of 'two predicate' constructions. This is also seen as influence from Dutch, where give-events are prototypically expressed with a single verbal predicate. The language history of individual heritage speakers indicates that speakers with a high exposure to Ambon Malay use this typical Ambonese construction more often than heritage speakers with a history of low exposure to Ambon Malay.

Thus, the divergence between heritage and homeland Ambon Malay giveconstructions does not involve a categorical change, but rather it manifests itself as a change in the frequency of already existing constructions. This 'restructuring by changing frequency' is partly due to the path of language acquisition of heritage Ambon Malay speakers, and partly due to contact with Dutch. Apart from quantitative differences, there are also qualitative differences between the give-constructions of heritage and homeland speakers of Ambon Malay: the different prepositions both groups choose for the PO construction reflect their different social histories. 
In conclusion, this study has shown once more that domains where languages allow variable syntax are susceptible to cross-linguistic effects. When the variable argument encodings of give-events in two languages are combined in the same, bilingual speaker, new frequency patterns emerge.

\section{Acknowledgements}

We would like to thank the participants in the study. Parts of this paper were presented at the Workshop 'Structural Change in Heritage Languages' in Noordwijkerhout, The Netherlands, 23-25 January 2013, and the 'Sixth Austronesian and Papuan Languages and Linguistics Conference (APLL6)', London, UK, 24-25 May 2013 and we thank the audiences at these occasions for their valuable input. We also wish to thank Harald Hammarström, Pablo Irizarri van Suchtelen, Gerrit Jan Kootstra, Pieter Muysken and two anonymous reviewers for their extremely useful comments on earlier versions of this paper. Any remaining errors are our responsibility. 


\section{Appendix 1}

Frequencies of give-constructions in Ambon Malay: individual data

\begin{tabular}{|c|c|c|c|c|c|c|c|}
\hline \multicolumn{2}{|c|}{ Homeland Speakers } & \multicolumn{5}{|c|}{ Type of construction } & \multirow[t]{2}{*}{ Total } \\
\hline & & Po & Do & $\begin{array}{l}\text { Recipient } \\
\text { omission }\end{array}$ & $\begin{array}{l}\text { Two } \\
\text { predicate }\end{array}$ & $\begin{array}{l}\text { Argument } \\
\text { fronting }\end{array}$ & \\
\hline \multirow[t]{2}{*}{$\mathrm{B}_{5}$} & Count & 4 & o & o & 2 & o & 6 \\
\hline & $\%$ within Speaker & $66.7 \%$ & o\% & o\% & $33 \cdot 3 \%$ & o\% & $100 \%$ \\
\hline \multirow[t]{2}{*}{$\mathrm{B}_{7}$} & Count & 3 & o & o & 3 & o & 6 \\
\hline & \% within Speaker & $50 \%$ & o\% & o\% & $50 \%$ & $0 \%$ & $100 \%$ \\
\hline \multirow[t]{2}{*}{$\mathrm{B} 2$} & Count & 4 & o & 0 & 2 & 0 & 6 \\
\hline & \% within Speaker & $66.7 \%$ & $\mathrm{o} \%$ & o\% & $33 \cdot 3 \%$ & o\% & $100 \%$ \\
\hline \multirow[t]{2}{*}{ B1 8} & Count & 6 & o & o & o & o & 6 \\
\hline & \% within Speaker & $100 \%$ & o\% & $0 \%$ & $0 \%$ & $0 \%$ & $100 \%$ \\
\hline \multirow[t]{2}{*}{ B8 } & Count & 4 & 1 & o & o & o & 5 \\
\hline & \% within Speaker & $80 \%$ & $20 \%$ & $0 \%$ & o\% & $0 \%$ & $100 \%$ \\
\hline \multirow[t]{2}{*}{$\mathrm{B}_{3}$} & Count & 2 & o & o & 2 & o & 4 \\
\hline & \% within Speaker & $50 \%$ & o\% & o\% & $50 \%$ & o\% & $100 \%$ \\
\hline \multirow[t]{2}{*}{$\mathrm{B} 24$} & Count & 4 & o & 0 & 2 & o & 6 \\
\hline & \% within Speaker & $66.7 \%$ & o\% & o\% & $33 \cdot 3 \%$ & o\% & $100 \%$ \\
\hline \multirow[t]{2}{*}{$\mathrm{B} 16$} & Count & 1 & o & 4 & o & o & 5 \\
\hline & \% within Speaker & $20 \%$ & o\% & $80 \%$ & o\% & o\% & $100 \%$ \\
\hline \multirow[t]{2}{*}{$\mathrm{B}_{4}$} & Count & 5 & o & o & o & o & 5 \\
\hline & \% within Speaker & $100 \%$ & $\mathrm{o} \%$ & o\% & o\% & o\% & $100 \%$ \\
\hline \multirow[t]{2}{*}{ B9 } & Count & 5 & o & o & o & o & 5 \\
\hline & \% within Speaker & $100 \%$ & o\% & o\% & $0 \%$ & o\% & $100 \%$ \\
\hline \multirow[t]{2}{*}{$\mathrm{B} 26$} & Count & 4 & o & o & o & o & 4 \\
\hline & \% within Speaker & $100 \%$ & o\% & $0 \%$ & o\% & o\% & $100 \%$ \\
\hline \multirow[t]{2}{*}{ B1 } & Count & 4 & o & o & 2 & o & 6 \\
\hline & $\%$ within Speaker & $66.7 \%$ & $\mathrm{o} \%$ & o\% & $33.3 \%$ & $0 \%$ & $100 \%$ \\
\hline \multirow[t]{2}{*}{ B19 } & Count & 4 & o & o & 2 & o & 6 \\
\hline & $\%$ within Speaker & $66.7 \%$ & o\% & o\% & $33.3 \%$ & $0 \%$ & $100 \%$ \\
\hline \multirow[t]{2}{*}{$\mathrm{B} 2 \mathrm{O}$} & Count & 5 & o & o & 1 & o & 6 \\
\hline & \% within Speaker & $83 \cdot 3 \%$ & o\% & o\% & $16.7 \%$ & o\% & $100 \%$ \\
\hline \multirow[t]{2}{*}{ B10 } & Count & 1 & o & o & 1 & o & 2 \\
\hline & \% within Speaker & $50 \%$ & o\% & o\% & $50 \%$ & $0 \%$ & $100 \%$ \\
\hline \multirow[t]{2}{*}{$\mathrm{B}_{21}$} & Count & 4 & o & o & 2 & o & 6 \\
\hline & \% within Speaker & $66.7 \%$ & o\% & o\% & $33 \cdot 3 \%$ & $0 \%$ & $100 \%$ \\
\hline
\end{tabular}


(cont.)

\begin{tabular}{|c|c|c|c|c|c|c|c|}
\hline \multicolumn{2}{|c|}{ Homeland Speakers } & \multicolumn{5}{|c|}{ Type of construction } & \multirow[t]{2}{*}{ Total } \\
\hline & & PO & Do & $\begin{array}{l}\text { Recipient } \\
\text { omission }\end{array}$ & $\begin{array}{l}\text { Two } \\
\text { predicate }\end{array}$ & $\begin{array}{l}\text { Argument } \\
\text { fronting }\end{array}$ & \\
\hline \multirow[t]{2}{*}{$\mathrm{B} 22$} & Count & 5 & o & o & 1 & o & 6 \\
\hline & \% within Speaker & $83 \cdot 3 \%$ & o\% & o\% & $16.7 \%$ & $0 \%$ & $100 \%$ \\
\hline \multirow[t]{2}{*}{ B11 } & Count & 4 & o & o & 1 & o & 5 \\
\hline & \% within Speaker & $80 \%$ & o\% & o\% & $20 \%$ & o\% & $100 \%$ \\
\hline \multirow[t]{2}{*}{ B6 } & Count & 6 & o & o & o & o & 6 \\
\hline & \% within Speaker & $100 \%$ & o\% & o\% & o\% & o\% & $100 \%$ \\
\hline \multirow[t]{2}{*}{$\mathrm{B}_{17}$} & Count & 5 & o & 1 & o & o & 6 \\
\hline & $\%$ within Speaker & $83 \cdot 3 \%$ & $0 \%$ & $16.7 \%$ & o\% & $0 \%$ & $100 \%$ \\
\hline \multirow[t]{2}{*}{$\mathrm{B}_{23}$} & Count & 2 & o & o & 3 & o & 5 \\
\hline & $\%$ within Speaker & $40 \%$ & $0 \%$ & $0 \%$ & $60 \%$ & $0 \%$ & $100 \%$ \\
\hline \multirow[t]{2}{*}{$\mathrm{B} 12$} & Count & 4 & o & o & 2 & o & 6 \\
\hline & $\%$ within Speaker & $66.7 \%$ & o\% & o\% & $33 \cdot 3 \%$ & $0 \%$ & $100 \%$ \\
\hline \multirow[t]{2}{*}{$\mathrm{B}_{13}$} & Count & 2 & o & o & 2 & 1 & 5 \\
\hline & \% within Speaker & $40 \%$ & $0 \%$ & $0 \%$ & $40 \%$ & $20 \%$ & $100 \%$ \\
\hline \multirow[t]{2}{*}{ B2 7} & Count & 6 & o & o & o & o & 6 \\
\hline & \% within Speaker & $100 \%$ & o\% & $0 \%$ & o\% & $0 \%$ & $100 \%$ \\
\hline \multirow[t]{2}{*}{ B25 } & Count & 1 & o & 1 & o & o & 2 \\
\hline & \% within Speaker & $50 \%$ & o\% & $50 \%$ & o\% & o\% & $100 \%$ \\
\hline \multirow[t]{2}{*}{ B14 } & Count & 5 & o & o & o & o & 5 \\
\hline & \% within Speaker & $100 \%$ & o\% & o\% & o\% & o\% & $100 \%$ \\
\hline \multirow[t]{2}{*}{$\mathrm{B}_{15}$} & Count & 2 & o & o & 2 & 0 & 4 \\
\hline & \% within Speaker & $50 \%$ & o\% & o\% & $50 \%$ & o\% & $100 \%$ \\
\hline \multirow[t]{2}{*}{ Total } & Count & 102 & 1 & 6 & 30 & 1 & 140 \\
\hline & \% within Speaker & $72.9 \%$ & $0.7 \%$ & $4.3 \%$ & $21.4 \%$ & $0.7 \%$ & $100 \%$ \\
\hline
\end{tabular}


First Generation Speakers Type of construction

Total

\begin{tabular}{llll}
\hline PO Do & $\begin{array}{l}\text { Recipient } \\
\text { omission }\end{array}$ & Two & Aredicate \\
& & & fronting
\end{tabular}

\begin{tabular}{|c|c|c|c|c|c|c|c|}
\hline \multirow[t]{2}{*}{ B29 } & Count & 1 & o\% & o & 3 & o & 4 \\
\hline & \% within Speaker & $25 \%$ & o & o\% & $75 \%$ & $0 \%$ & $100 \%$ \\
\hline \multirow[t]{2}{*}{$\mathrm{B}_{31}$} & Count & 3 & $0 \%$ & o & 1 & 2 & 6 \\
\hline & $\%$ within Speaker & $50 \%$ & o & $0 \%$ & $16.7 \%$ & $33 \cdot 3 \%$ & $100 \%$ \\
\hline \multirow[t]{2}{*}{$\mathrm{B} 28$} & Count & 4 & o\% & o & 1 & o & 5 \\
\hline & \% within Speaker & $80 \%$ & o & $0 \%$ & $20 \%$ & $0 \%$ & $100 \%$ \\
\hline \multirow[t]{2}{*}{$\mathrm{B}_{33}$} & Count & o & o\% & 1 & 1 & o & 2 \\
\hline & \% within Speaker & o\% & o & $50 \%$ & $50 \%$ & $0 \%$ & $100 \%$ \\
\hline \multirow[t]{2}{*}{$\mathrm{B}_{30}$} & Count & 5 & o\% & o & 1 & o & 6 \\
\hline & $\%$ within Speaker & $83.3 \%$ & o & o\% & $16.7 \%$ & $0 \%$ & $100 \%$ \\
\hline \multirow[t]{2}{*}{$\mathrm{B}_{32}$} & Count & 3 & o\% & 1 & 1 & 1 & 6 \\
\hline & $\%$ within Speaker & $50 \%$ & o & $16.7 \%$ & $16.7 \%$ & $16.7 \%$ & $100 \%$ \\
\hline \multirow[t]{2}{*}{ Total } & Count & 16 & o\% & 2 & 8 & 3 & 29 \\
\hline & $\%$ within Speaker & $55.2 \%$ & o & $6.9 \%$ & $27.6 \%$ & $10.3 \%$ & $100 \%$ \\
\hline
\end{tabular}

Heritage Speakers

Type of construction

Total

$\begin{array}{llll}\text { PO Do } & \begin{array}{l}\text { Recipient } \\ \text { omission }\end{array} & \begin{array}{l}\text { Two } \\ \text { predicate }\end{array} & \begin{array}{l}\text { Argument } \\ \text { fronting }\end{array}\end{array}$

\begin{tabular}{|c|c|c|c|c|c|c|c|}
\hline \multirow[t]{2}{*}{$\mathrm{H} 22$} & Count & 4 & 1 & o & o & o & 5 \\
\hline & \% within Speaker & $80 \%$ & $20 \%$ & o\% & o\% & o\% & $100 \%$ \\
\hline \multirow[t]{2}{*}{$\mathrm{H}_{31}$} & Count & 1 & o & o & 2 & 3 & 6 \\
\hline & \% within Speaker & $16.7 \%$ & $0 \%$ & $0 \%$ & $33 \cdot 3 \%$ & $50 \%$ & $100 \%$ \\
\hline \multirow[t]{2}{*}{$\mathrm{H}_{1}$} & Count & 5 & o & o & 1 & o & 6 \\
\hline & \% within Speaker & $83.3 \%$ & $0 \%$ & $0 \%$ & $16.7 \%$ & $0 \%$ & $100 \%$ \\
\hline \multirow[t]{2}{*}{$\mathrm{H} 9$} & Count & 4 & o & 1 & o & o & 5 \\
\hline & \% within Speaker & $80 \%$ & $0 \%$ & $20 \%$ & $0 \%$ & o\% & $100 \%$ \\
\hline \multirow[t]{2}{*}{$\mathrm{H} 23$} & Count & 6 & o & o & o & o & 6 \\
\hline & \% within Speaker & $100 \%$ & $0 \%$ & o\% & o\% & o\% & $100 \%$ \\
\hline \multirow[t]{2}{*}{$\mathrm{H}_{12}$} & Count & 2 & o & 1 & 3 & o & 6 \\
\hline & \% within Speaker & $33 \cdot 3 \%$ & $0 \%$ & $16.7 \%$ & $50 \%$ & $0 \%$ & $100 \%$ \\
\hline
\end{tabular}


(cont.)

Heritage Speakers

Type of construction

Total

\section{PO Do Recipient Two Argument omission predicate fronting}

\begin{tabular}{|c|c|c|c|c|c|c|c|}
\hline \multirow[t]{2}{*}{$\mathrm{H}_{11}$} & Count & 3 & o & o & o & o & 3 \\
\hline & \% within Speaker & $100 \%$ & o\% & $0 \%$ & $0 \%$ & $0 \%$ & $100 \%$ \\
\hline \multirow[t]{2}{*}{$\mathrm{H}_{15}$} & Count & 3 & o & o & 1 & 1 & 5 \\
\hline & \% within Speaker & $60 \%$ & $0 \%$ & $0 \%$ & $20 \%$ & $20 \%$ & $100 \%$ \\
\hline \multirow[t]{2}{*}{$\mathrm{H}_{3}$} & Count & 5 & o & o & 1 & o & 6 \\
\hline & \% within Speaker & $83.3 \%$ & $0 \%$ & o\% & $16.7 \%$ & $0 \%$ & $100 \%$ \\
\hline \multirow[t]{2}{*}{$\mathrm{H}_{17}$} & Count & 3 & 3 & o & o & o & 6 \\
\hline & \% within Speaker & $50 \%$ & $50 \%$ & $0 \%$ & o\% & o\% & $100 \%$ \\
\hline \multirow[t]{2}{*}{$\mathrm{H} 29$} & Count & 4 & 1 & 1 & o & o & 6 \\
\hline & \% within Speaker & $66.7 \%$ & $16.7 \%$ & $16.7 \%$ & o\% & o\% & $100 \%$ \\
\hline \multirow[t]{2}{*}{$\mathrm{H}_{4}$} & Count & 3 & o & 1 & o & 2 & 6 \\
\hline & \% within Speaker & $50 \%$ & o\% & $16.7 \%$ & $0 \%$ & $33 \cdot 3 \%$ & $100 \%$ \\
\hline \multirow[t]{2}{*}{ H6 } & Count & 5 & 1 & o & o & o & 6 \\
\hline & \% within Speaker & $83.3 \%$ & $16.7 \%$ & o\% & $0 \%$ & $0 \%$ & $100 \%$ \\
\hline \multirow[t]{2}{*}{$\mathrm{H} 25$} & Count & 3 & 1 & o & o & o & 4 \\
\hline & \% within Speaker & $75 \%$ & $25 \%$ & o\% & $0 \%$ & $0 \%$ & $100 \%$ \\
\hline \multirow[t]{2}{*}{$\mathrm{H}_{1} 6$} & Count & 3 & 1 & 1 & 1 & o & 6 \\
\hline & \% within Speaker & $50 \%$ & $16.7 \%$ & $16.7 \%$ & $16.7 \%$ & o\% & $100 \%$ \\
\hline \multirow[t]{2}{*}{$\mathrm{H} 2 \mathrm{O}$} & Count & 5 & o & 1 & o & o & 6 \\
\hline & $\%$ within Speaker & $83 \cdot 3 \%$ & $0 \%$ & $16.7 \%$ & $0 \%$ & $0 \%$ & $100 \%$ \\
\hline \multirow[t]{2}{*}{$\mathrm{H}_{19}$} & Count & 5 & 1 & o & o & o & 6 \\
\hline & \% within Speaker & $83.3 \%$ & $16.7 \%$ & $0 \%$ & o\% & o\% & $100 \%$ \\
\hline \multirow[t]{2}{*}{$\mathrm{H}_{3} \mathrm{O}$} & Count & 2 & 1 & 3 & o & o & 6 \\
\hline & \% within Speaker & $33 \cdot 3 \%$ & $16.7 \%$ & $50 \%$ & o\% & o\% & $100 \%$ \\
\hline \multirow[t]{2}{*}{$\mathrm{H}_{2} 8$} & Count & 2 & 3 & 1 & o & o & 6 \\
\hline & \% within Speaker & $33 \cdot 3 \%$ & $50 \%$ & $16.7 \%$ & o\% & o\% & $100 \%$ \\
\hline \multirow[t]{2}{*}{ H8 } & Count & 5 & o & o & 1 & o & 6 \\
\hline & \% within Speaker & $83 \cdot 3 \%$ & $0 \%$ & $0 \%$ & $16.7 \%$ & $0 \%$ & $100 \%$ \\
\hline \multirow[t]{2}{*}{$\mathrm{H}_{2} 6$} & Count & 6 & o & o & o & o & 6 \\
\hline & \% within Speaker & $100 \%$ & $0 \%$ & $0 \%$ & $0 \%$ & $0 \%$ & $100 \%$ \\
\hline \multirow[t]{2}{*}{$\mathrm{H}_{32}$} & Count & 3 & 1 & o & 2 & o & 6 \\
\hline & \% within Speaker & $50 \%$ & $16.7 \%$ & o\% & $33 \cdot 3 \%$ & o\% & $100 \%$ \\
\hline
\end{tabular}




\begin{tabular}{|c|c|c|c|c|c|c|c|}
\hline \multicolumn{2}{|c|}{ Heritage Speakers } & \multicolumn{5}{|c|}{ Type of construction } & \multirow[t]{2}{*}{ Total } \\
\hline & & PO & Do & $\begin{array}{l}\text { Recipient } \\
\text { omission }\end{array}$ & $\begin{array}{l}\text { Two } \\
\text { predicate }\end{array}$ & $\begin{array}{l}\text { Argument } \\
\text { fronting }\end{array}$ & \\
\hline $\mathrm{H} 24$ & $\begin{array}{l}\text { Count } \\
\text { \% within Speaker }\end{array}$ & $\begin{array}{l}2 \\
40 \%\end{array}$ & $\begin{array}{l}3 \\
60 \%\end{array}$ & $\begin{array}{l}\mathrm{o} \\
\mathrm{o} \%\end{array}$ & $\begin{array}{l}\mathrm{o} \\
\mathrm{o} \%\end{array}$ & $\begin{array}{l}\mathrm{o} \\
\mathrm{o} \%\end{array}$ & $\begin{array}{l}5 \\
100 \%\end{array}$ \\
\hline $\mathrm{H}_{33}$ & $\begin{array}{l}\text { Count } \\
\text { \% within Speaker }\end{array}$ & $\begin{array}{l}4 \\
66.7 \%\end{array}$ & $\begin{array}{l}1 \\
16.7 \%\end{array}$ & $\begin{array}{l}1 \\
16.7 \%\end{array}$ & $\begin{array}{l}\mathrm{o} \\
\mathrm{o} \%\end{array}$ & $\begin{array}{l}\mathrm{o} \\
\mathrm{o} \%\end{array}$ & $\begin{array}{l}6 \\
100 \%\end{array}$ \\
\hline $\mathrm{H} 27$ & $\begin{array}{l}\text { Count } \\
\text { \% within Speaker }\end{array}$ & $\begin{array}{l}5 \\
83 \cdot 3 \%\end{array}$ & $\begin{array}{l}\mathrm{o} \\
\mathrm{o} \%\end{array}$ & $\begin{array}{l}1 \\
16.7 \%\end{array}$ & $\begin{array}{l}\mathrm{o} \\
\mathrm{o} \%\end{array}$ & $\begin{array}{l}\mathrm{o} \\
\mathrm{o} \%\end{array}$ & $\begin{array}{l}6 \\
100 \%\end{array}$ \\
\hline $\mathrm{H} 18$ & $\begin{array}{l}\text { Count } \\
\text { \% within Speaker }\end{array}$ & $\begin{array}{l}4 \\
66.7 \%\end{array}$ & $\begin{array}{l}\mathrm{o} \\
\mathrm{o} \%\end{array}$ & $\begin{array}{l}\mathrm{o} \\
\mathrm{o} \%\end{array}$ & $\begin{array}{l}2 \\
33 \cdot 3 \%\end{array}$ & $\begin{array}{l}\mathrm{o} \\
\mathrm{o} \%\end{array}$ & $\begin{array}{l}6 \\
100 \%\end{array}$ \\
\hline $\mathrm{H} 21$ & $\begin{array}{l}\text { Count } \\
\text { \% within Speaker }\end{array}$ & $\begin{array}{l}4 \\
80 \%\end{array}$ & $\begin{array}{l}\mathrm{o} \\
\mathrm{o} \%\end{array}$ & $\begin{array}{l}\mathrm{o} \\
\mathrm{o} \%\end{array}$ & $\begin{array}{l}1 \\
20 \%\end{array}$ & $\begin{array}{l}\mathrm{o} \\
\mathrm{o} \%\end{array}$ & $\begin{array}{l}5 \\
100 \%\end{array}$ \\
\hline $\mathrm{H}_{5}$ & $\begin{array}{l}\text { Count } \\
\text { \% within Speaker }\end{array}$ & $\begin{array}{l}5 \\
83 \cdot 3 \%\end{array}$ & $\begin{array}{l}\mathrm{o} \\
\mathrm{o} \%\end{array}$ & $\begin{array}{l}1 \\
16.7 \%\end{array}$ & $\begin{array}{l}\mathrm{o} \\
\mathrm{o} \%\end{array}$ & $\begin{array}{l}\mathrm{o} \\
\mathrm{o} \%\end{array}$ & $\begin{array}{l}6 \\
100 \%\end{array}$ \\
\hline $\mathrm{H}_{13}$ & $\begin{array}{l}\text { Count } \\
\text { \% within Speaker }\end{array}$ & $\begin{array}{l}4 \\
80 \%\end{array}$ & $\begin{array}{l}1 \\
20 \%\end{array}$ & $\begin{array}{l}\mathrm{o} \\
\mathrm{o} \%\end{array}$ & $\begin{array}{l}\mathrm{o} \\
\mathrm{o} \%\end{array}$ & $\begin{array}{l}\mathrm{o} \\
\mathrm{o} \%\end{array}$ & $\begin{array}{l}5 \\
100 \%\end{array}$ \\
\hline $\mathrm{H}_{14}$ & $\begin{array}{l}\text { Count } \\
\text { \% within Speaker }\end{array}$ & $\begin{array}{l}5 \\
83 \cdot 3 \%\end{array}$ & $\begin{array}{l}\mathrm{o} \\
\mathrm{o} \%\end{array}$ & $\begin{array}{l}\mathrm{o} \\
\mathrm{o} \%\end{array}$ & $\begin{array}{l}1 \\
16.7 \%\end{array}$ & $\begin{array}{l}\mathrm{o} \\
\mathrm{o} \%\end{array}$ & $\begin{array}{l}6 \\
100 \%\end{array}$ \\
\hline $\mathrm{H}_{7}$ & $\begin{array}{l}\text { Count } \\
\% \text { within Speaker }\end{array}$ & $\begin{array}{l}5 \\
83 \cdot 3 \%\end{array}$ & $\begin{array}{l}\mathrm{o} \\
\mathrm{o} \%\end{array}$ & $\begin{array}{l}1 \\
16.7 \%\end{array}$ & $\begin{array}{l}\mathrm{o} \\
\mathrm{o} \%\end{array}$ & $\begin{array}{l}\mathrm{o} \\
\mathrm{o} \%\end{array}$ & $\begin{array}{l}6 \\
100 \%\end{array}$ \\
\hline $\mathrm{H}_{2}$ & $\begin{array}{l}\text { Count } \\
\% \text { within Speaker }\end{array}$ & $\begin{array}{l}2 \\
33 \cdot 3 \%\end{array}$ & $\begin{array}{l}1 \\
16.7 \%\end{array}$ & $\begin{array}{l}2 \\
33 \cdot 3 \%\end{array}$ & $\begin{array}{l}1 \\
16.7 \%\end{array}$ & $\begin{array}{l}\mathrm{o} \\
\mathrm{o} \%\end{array}$ & $\begin{array}{l}6 \\
100 \%\end{array}$ \\
\hline Total & $\begin{array}{l}\text { Count } \\
\% \text { within Speaker }\end{array}$ & $\begin{array}{l}122 \\
67.4 \%\end{array}$ & $\begin{array}{l}20 \\
11 \%\end{array}$ & $\begin{array}{l}16 \\
8.8 \%\end{array}$ & $\begin{array}{l}17 \\
9 \cdot 4 \%\end{array}$ & $\begin{array}{l}6 \\
3 \cdot 3 \%\end{array}$ & $\begin{array}{l}181 \\
100 \%\end{array}$ \\
\hline
\end{tabular}

\section{References}

Aalberse, Suzanne and Muysken, Pieter. 2013. Perspective on heritage languages. Position paper for the Workshop on 'Structural changes in heritage languages'. Downloadable at http://www.ru.nl/linc/news_and_events/events/workshop-'structural/ \#PositionPaper (Accessed on July 18, 2014).

Adelaar, Karl Alexander and Prentice, David John. 1996. Malay: its history, role and spread. In Wurm, Stephen A., Mühlhäusler, Peter and Tryon, Darrell T. (eds.), Atlas of Languages of Intercultural Communication in the Pacific, Asia and the Americas, Vol. II.1, 673-693. Berlin: Mouton de Gruyter. 
Backus, Ad. 2004. Convergence as a mechanism of language change. Bilingualism Language and Cognition, $7(2): 179-181$.

Baxter, Alan. 1990. Some observations on verb serialization in Malacca Creole Portuguese. Boletim de Filologia, 31: 161-184.

Boumans, Louis. 2006. The attributive possessive in Moroccan Arabic spoken by young bilinguals in the Netherlands and their peers in Morocco. Bilingualism: Language and Cognition, 9(3): 213-231.

Bresnan, Joan, Cueni, Anna, Nikitina, Tatiana and Baayen, Harald. 2007. Predicting the dative alternation. In Boume, Gerlof, Kraemer, Irene, and Zwarts, Joost (eds.), Cognitive Foundations of Interpretation, 69-94. Amsterdam: Royal Academy of Science.

Broekhuis, Hans, Corver, Norbert and Vos, Riet. 2015. Syntax of Dutch: Verbs and Verb Phrases, Volume I. Amsterdam University Press.

Bruyn, Adrienne, Muysken, Pieter and Verrips, Maaike. 1999. Double-object constructions in the creole languages: development and acquisition. In DeGraff, Michel (ed.), Language creation and language change, 329-37. Cambridge, MA: MIT Press.

Carroll, Mary and von Stutterheim, Christiane. 2003. Typology and information organisation: perspective taking and language-specific effects in the construal of events. In Ramat, Anna G. (ed.), Typology and second Language Acquisition, 365-403. Berlin: Mouton de Gruyter.

Chevalier, Joan. 2004. Heritage Language Literacy: Theory and Practice. Heritage Language Journal, 2(1): 1-19.

Colleman, Timothy. 2009. Verb disposition in argument structure alternations: a corpus study of the dative alternation in Dutch. Language Sciences, 31: 593-611.

Colleman, Timothy. 2006. De Nederlandse datiefalternatie. Een constructioneel en corpus-gebaseerd onderzoek. Ph.D. dissertation, Ghent University.

Colleman, Timothy, and Bernolet, Sarah. 2012. Alternation biases in corpora vs. picture description experiments: DO-biased and PD-biased verbs in the Dutch dative alternation. In DagmarDivjak and Gries, Stefan Th. (eds.), Frequency Effects in Language Representation, 87-125. Berlin/Boston: Walter de Gruyter.

Dryer, Matthew S. 2007. Clause types. In Shopen, Timothy (ed), Language typology and syntactic description, Volume I, Clause structure, 224-275. Cambridge: Cambridge University Press.

Grimes, Barbara Dix. 1991. The development and use of Ambonese Malay. Pacific Linguistics, A-81: 83-123.

Haspelmath, Martin. 2011. On S, A, P, T, and R as comparative concepts for alignment typology. Linguistic Typology, 15(3): 535-567.

Huwaë, Rosita.1992. Tweetaligheid in Wierden: het taalgebruik van jongeren uit een Molukse gemeenschap. Ph.D. dissertation, University of Amsterdam.

Irizarri van Suchtelen, Pablo. 2014. Maintained and acquired heritage Spanish in the Netherlands: The case of dative constructions. Applied Linguistics Review, 5(2): 375-400. 
Lekawael, Rosina. 2011. The development of Moluccan Malay as a heritage language in the Netherlands. MA thesis, Radboud University.

Malchukov, Andrej, Haspelmath, Martin and Comrie, Bernard. 2010. Ditransitive constructions: a typological overview. In Malchukov, Andrej, Haspelmath, Martin and Comrie, Bernard (eds.), Studies in Ditransitive Constructions: A Comparative Handbook, 1-64. Berlin and New York: Mouton de Gruyter.

Mazurkewich, Irene and White, Lydia. 1984. The acquisition of the dative alternation: Unlearning overgeneralizations. Cognition, 16: 261-283.

Michaelis, Susanne and Haspelmath, Martin. 2003. Ditransitive constructions: Creole languages in a cross-linguistic perspective. Creolica, 23(4)(Available online at www .creolica.net/michaelis.pdf ) (Accessed on July 18, 2014).

Haspelmath, Martin, Michaelis, Susanne Maria and the APiCS Consortium. 2013. Ditransitive constructions with 'give'. In: Michaelis, Susanne Maria \& Maurer, Philippe \& Haspelmath, Martin \& Huber, Magnus (eds.) Atlas of Pidgin and Creole Language Structures Online. Leipzig: Max Planck Institute for Evolutionary Anthropology. (Available online at http://apics-online.info/parameters/6o) (Accessed on July 18, 2014).

Minde, Don van. 1997. Malayu Ambong. Research School CNWS, Leiden University, the Netherlands.

Montrul, Silvina and Bowles, Melissa. 2009. Back to basics: incomplete knowledge of differential object marking in Spanish heritage speakers. Bilingualism: Language and Cognition, $12(3): 363-383$.

Moro, Francesca. 2014. Resultative constructions in heritage Ambon Malay in the Netherlands. Linguistics in the Netherlands 31(1): 78-92.

Muysken, Pieter. 2013. Language contact outcomes as the result of bilingual optimization strategies. Bilingualism: Language and Cognition, 16(4), 709-730.

Onar Valk, Pelin and Backus, Ad. 2013. Syntactic change in an immigrant language: from non-finite to finite subordinate clauses in Turkish. Eesti ja soome-ugri keeleteaduse ajakiri.Journal of Estonian and Finno-Ugric Linguistics, 4(2): 7-29.

Paauw, Scott. 2008. The Malay contact varieties of Eastern Indonesia: a typological comparison. Ph.D. dissertation, State University of New York at Buffalo.

Polinsky, Maria. 1998. A non-syntactic account of some asymmetries in the double object construction. In Koenig, Jean-Pierre (ed.), Discourse and Cognition: Bridging the Gap, 403-422. Stanford: CSLI Publications.

Polinsky, Maria and Kagan, Olga. 2007. Heritage languages: In the 'wild' and in the classroom. Language and Linguistics Compass, 1(5): 368-395.

Şahin, Hulya and Kootstra, Gerrit Jan. 2011. Cross-linguistic interaction in the production of dative structures by Papiamento-Dutch bilinguals: Evidence from crosslanguage structural priming. Poster Presentation, Workshop Frontiers in Linguistics, Acquisition, and Multilingualism Studies: Dynamic paradigms, Kerkrade (The Netherlands), 13 May 2011. 
Schoonbaert, Sofie, Hartsuiker, Robert J., and Pickering, Martin J. 2007. The representation of lexical and syntactic information in bilinguals: Evidence from syntactic priming. Journal of Memory and Language, 56(2):153-171.

Silva-Corvalán, Carmen. 1993. On the permeability of grammars: evidence from Spanish and English contact. In Ashby William J., Mithun Marianne, Perissinotto, Giorgio, and Eduardo, Raposo E. (eds.) Selected papers from the 21st symposium on Romance Languages, 19-43. Amsterdam: John Benjamins.

Silva-Corvalán, Carmen. 1994. Language Contact and Change: Spanish in Los Angeles. Language Variation and Change. Oxford: Clarendon Press.

Silva-Corvalán, Carmen. 2008. The limits of convergence in language contact. Journal of Language Contact, 2(1): 213-224.

Slobin, Dan. 1991. Learning to think for speaking: Homeland language, cognition, and rhetorical style. Pragmatics, 1: 7-26.

Soolsma, Rowan. 2013. De progressief in het Nederlands en het Moluks Maleis. MA thesis: Radboud University.

Staden, Miriam van and Reesink, Ger. 2008. Serial verb constructions in a linguistic area. In Senft, Gunter (ed.), Serial verb constructions in Austronesian and Papuan languages, 17-54. Canberra: Research School of Pacific and Asian Studies, The Australian National University.

Tahitu, Bert. 1989. Melaju Sini. Het Maleis van Molukse jongeren in Nederland. Ph.D. dissertation, Leiden University.

Theijssen, Daphne. 2012. Making choices: Modelling the English dative alternation. Ph.D. dissertation, Radboud University.

Tjia, Johnny. 1997. Verb serialization in Ambonese Malay. MA Thesis, University of Oregon.

Veenman, Justus. 1994. The social integration of Moluccans. Rotterdam: Koninklijke Vermande/ISEO.

Voigt, Herman. 1994. Code-wisseling, taalverschuiving en taalverandering in het Melaju Sini. Ph.D. dissertation, University of Tilburg.

Wasow, Thomas. 2002. Postverbal behavior. Stanford: CSLI.

Whong-Barr, Melinda and Schwartz, Bonnie D. 2002. Morphological and syntactic transfer in child L2 acquisition of the English dative alternation. Studies in Second Language Acquisition, 24: 579-616.

Yip, Virginia and Matthews, Stephen. 2007. The bilingual child: Early development and language contact. Cambridge: Cambridge University Press. 